\title{
المسئولية الأخلاقية لإتقان العمل في ضوي الكتاب والسنة
}

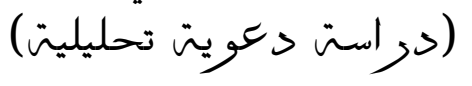

مقدمة:

الحمد للّه رب العالمين نحمده ونستغفره ونستهديه ونتوكل عليه،

ونصلي ونسلم على نبي الهدى محمد بن عبد اللّه خاتم النبيين وعلى آله وصحبه

$$
\text { أجمعين وعلى من تبعهم بإحسان إلى يوم الدين. }
$$

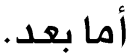

فقد اهتم الإسلام بالعمل اهتماماً شديداً في مصادره الأصيلة، الكتاب

والسنة، ومن ثم فقد أبرزت العقيدة الإسلامية - المسئولية الأخلاقية التي يجب أن يتم العمل في إطارها - فهماً وإدراكاً وإتقاناً وإبداعاً دون مِّل إلى التكاسل والتباطؤ والتواكل. فالمسئولية أقوى دعامة ربانية يتم من خلالها الفهم الصحيح لجوهر العمل، وإتقانه والإخلاص فيه والاستفادة منه وخروجه من دائرة الأقوال إلى دائرة الأفعال، وذلك على كافة الأصعدة سواء" أكانت الأعمال دينية" أو 


\section{المبحث الأول . التعريف بهمطاحات البحث}

\section{الإسئوئية - الأخلاق - الإثمان - العمل}

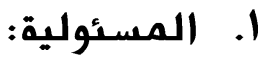

في اللغة: يقول ابن منظور : من مادة " سأل" التي تدل على استدعاء معرفة أو ما يؤدي إلى المعرفة'. و قال الراغب: فاستدعاء المعرفة فجوابه على اللسان،

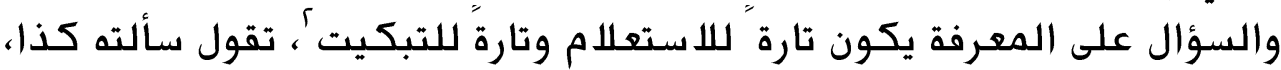

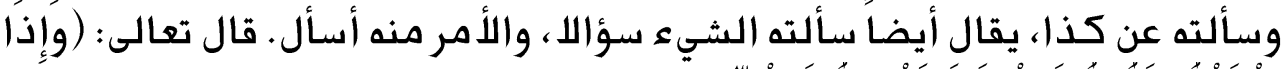

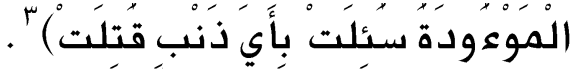
وفي الاصطالام:

فالمسـولية استعداد فطري بالزام المرء نفسه أن يقوم بكافة ما يوكل إليه من عمل بكفاءة واقتدار، وهي علاقة مزدوجة من ناحية الفرد المسئول بأعماله،

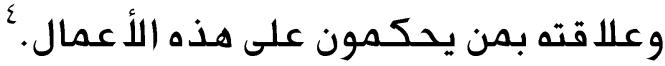
وقيل المسئولية هي الشعور بأداء التبعة والواجب والإخلاص في العمل، بحيث هـيث يكون الإنسان صالحاً للمؤاخذة على أعماله وملزماً بتبعاتها المختلفة . قال قال

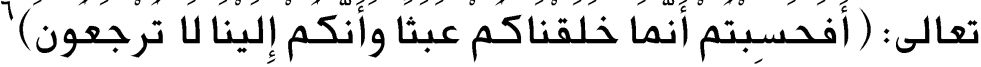
أنواع المسـئولية: ا. دينية: وهي التزام المرء بأوامر الله تعالى شرعة ومنهاجا، وآدابا وقيما، وقبوله في حال المخالفة العقوبة الأزمة لذلك. ז. مسئولية اجتماعية: وهي التزام المرء بأعرف المجتمع ونظمه وتقاليده ومرتكزاتها و الاهتمام والفهم والمشاركة. س. مسئولية أخلاقية: وهي حالة تمنح المرء القدرة على تحمل تبعات أعماله

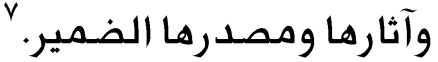

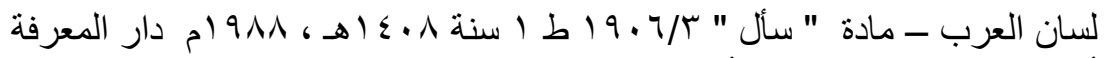

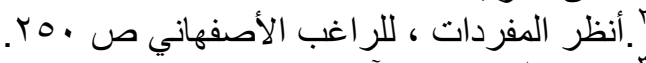

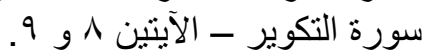

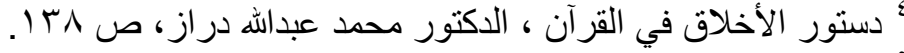

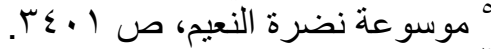

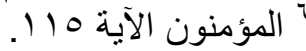

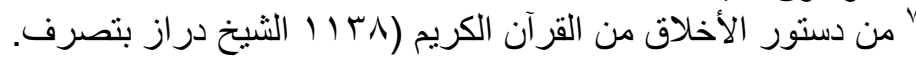


فكل مسئولية قبلها الإنسان وارتضاها والتزم بها فهي تدخل في سياق المسئولية

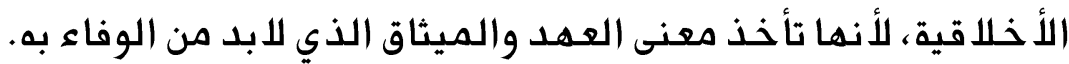

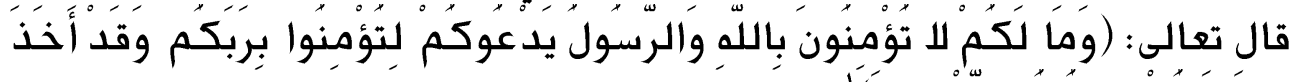

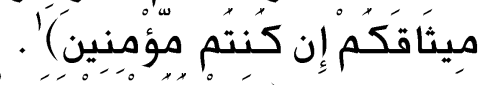

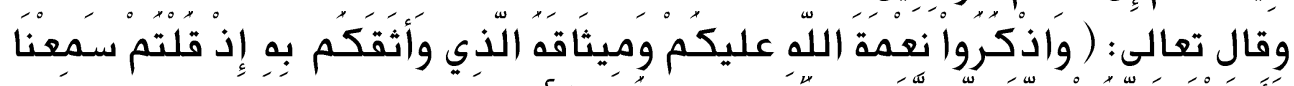

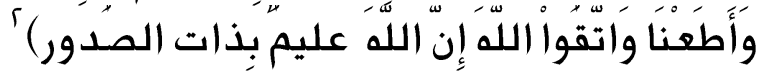

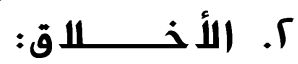
ففي اللغة: من مادة " خلق " والخلقُ بضم اللام وسكونها وهو الدين والطبع

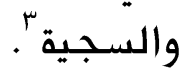

وفي الاصطلاح: صورة الإنسان الباطنة وهي نفسه، وأوصافها ومعانيها المختصة

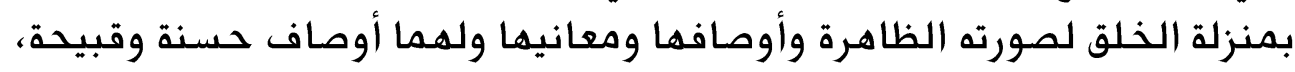
والثواب والعقاب مما يتعلقان بأوصاف الصورة الباطنة أكثر مما يتعلقان

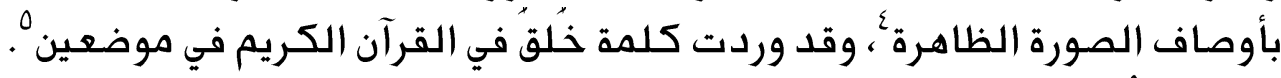

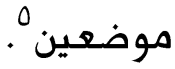

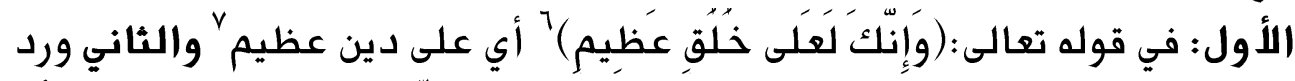

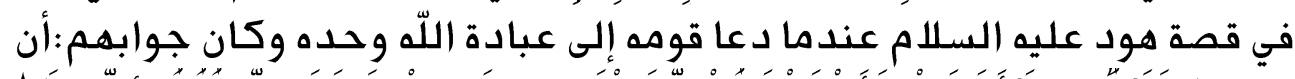

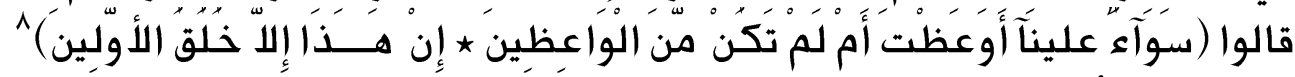

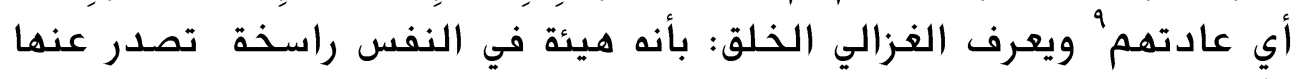

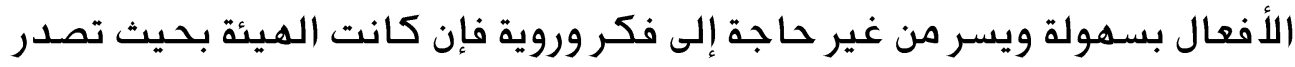

$$
\begin{aligned}
& \text { سورة الحديد، الآيةه. }
\end{aligned}
$$

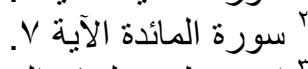

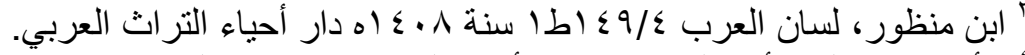

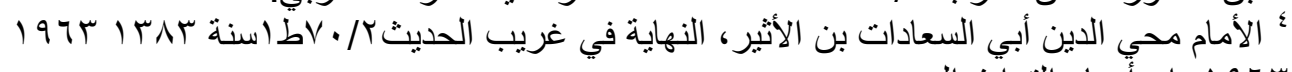

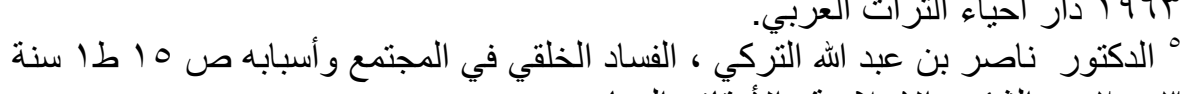

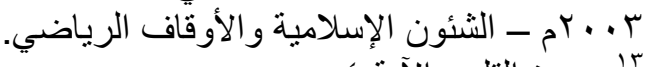

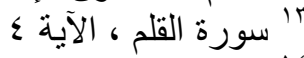

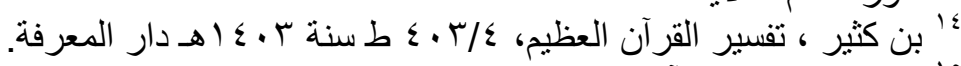

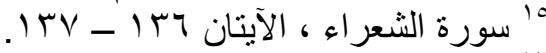

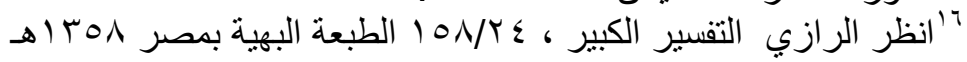


عنها الأفعال الجميلة المحمودة عقلاً وشرعاً سميت تلك الهيئة خلقاً حسناً، وإن

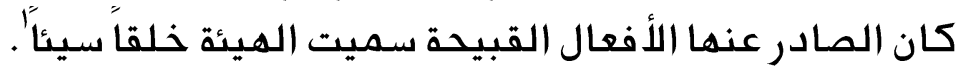

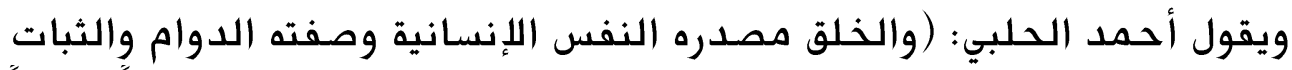

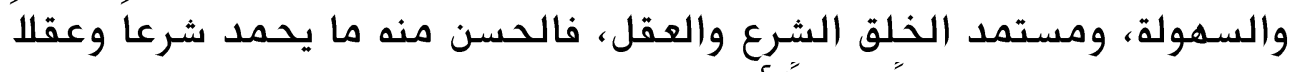

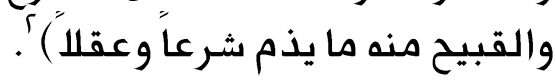
فالأعمال جميعها ظاهرها وباطنها، خيرها وشرها، صغيرها وكبيرها وفا ضابطها

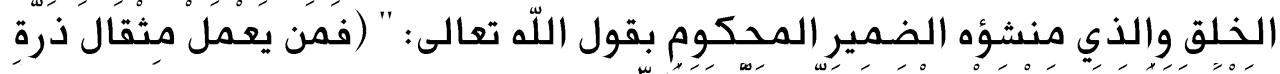

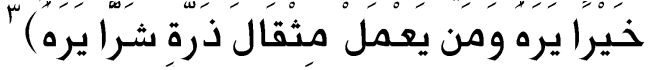

$$
\begin{aligned}
& \text { مصطلح الإتقان: }
\end{aligned}
$$

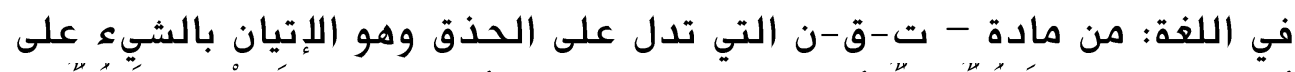

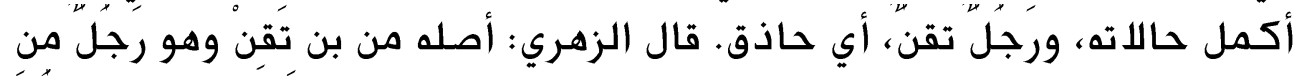

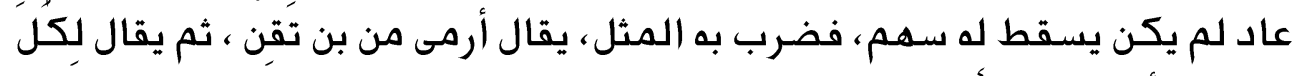

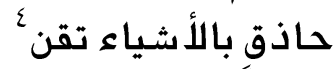

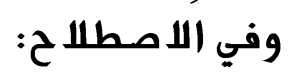

الإنقان: الإحكام للأشياء وإحسانها تقول " أتقن فلان عمله إذا أحكمه ورأتقن

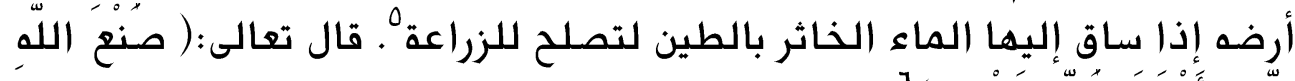

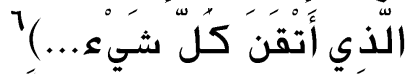

$$
\begin{aligned}
& \text { مصطلح العمل: } \\
& \text { في اللغة: هو الحرفة، أو المهنة، أو الصنعة. }
\end{aligned}
$$

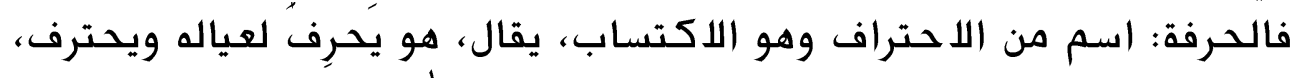

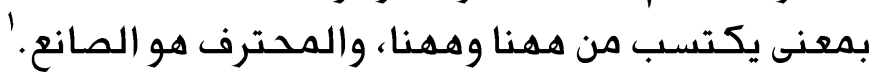

' الإمام الغز الي ، إحياء علوم الدين س/ به ط دار المعرفة، بيروت.

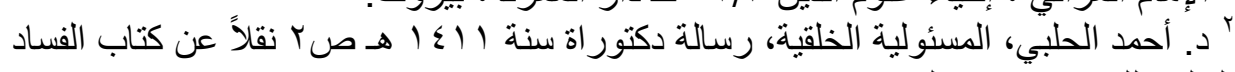

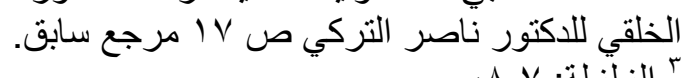

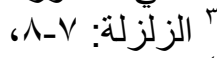

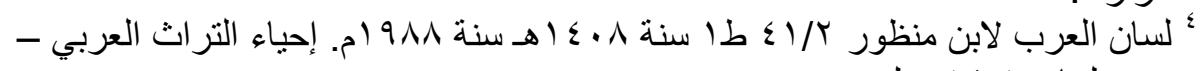

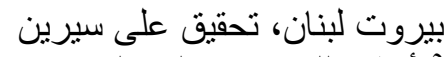

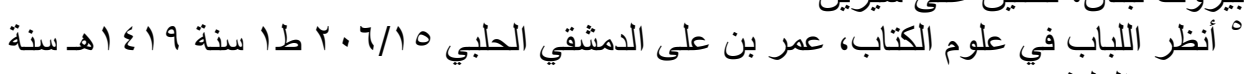




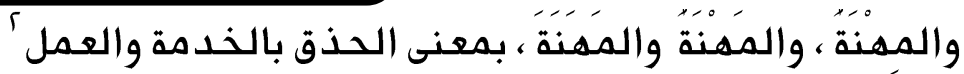

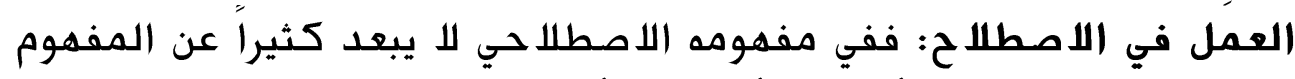

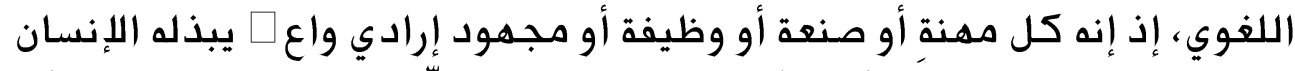

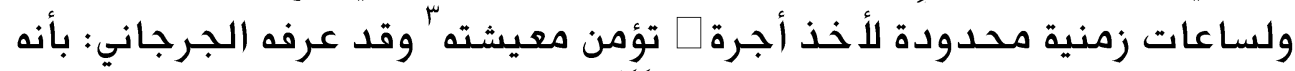

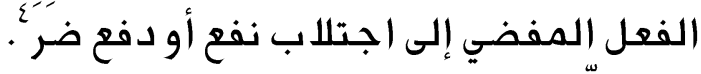

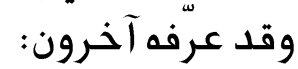

بأنه نشاط تلقائي أو مكتبي ذهني أو جسمي يهدف إلى غاية ويصدر عن إرادة ويخضع لحكم أخلاقي" "0. وفي الكليات لأبي البقاء: العمل لإديمال يقال إلا فيما كان عن فكرِ وروية ولهذا قرن

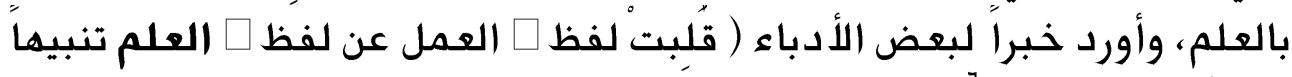

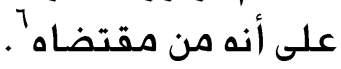

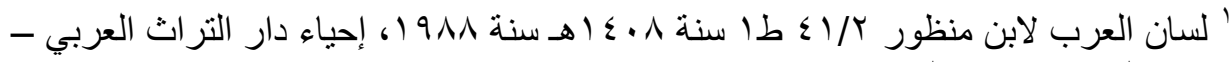

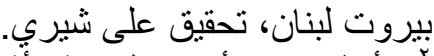

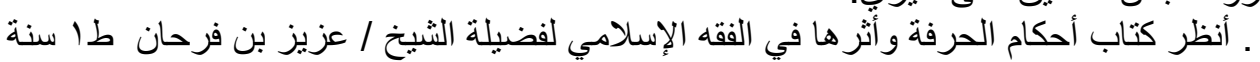

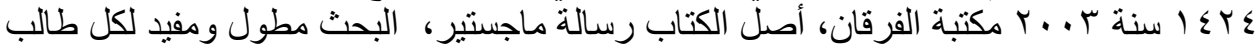

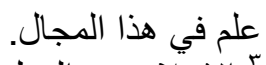

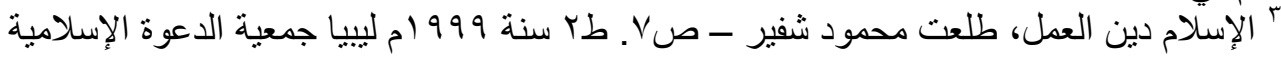

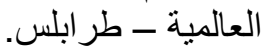

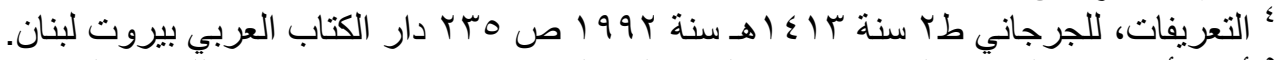

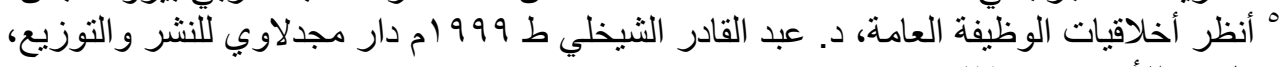

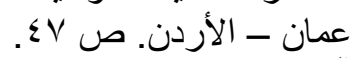

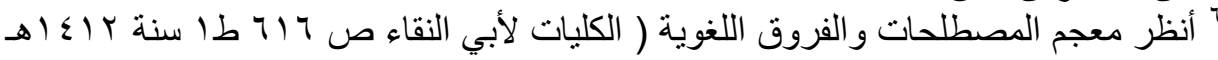




\section{المبحث الثهازي : المهل في ميزان الإبلام}

المطلب الأول: مضامين العمل وأبعاده:

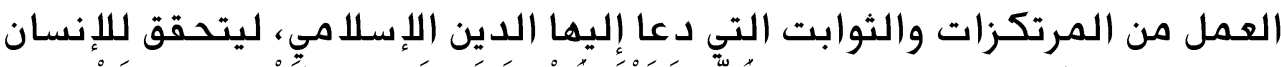

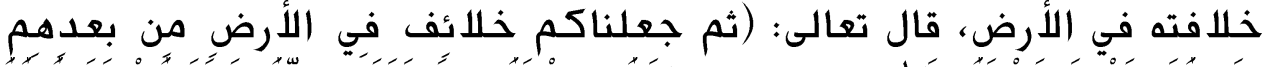

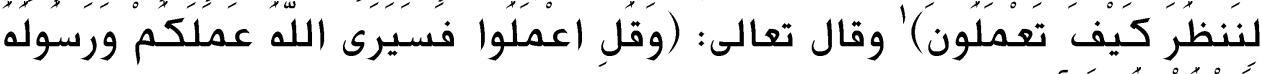

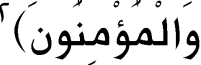

فالعـمل من القيم الدينية التي تتحقق بها الحكمة من خلق الإنسان ووجوده في هذه الحياة إذ أن العمل الصالح المبدع المؤثر الفاعل بكافة ضروبه، هو إنتاج ذهني، فكري أخلاقي يعد من العبادة المتعدية التي يصل نفعها للآ خرين فضلا

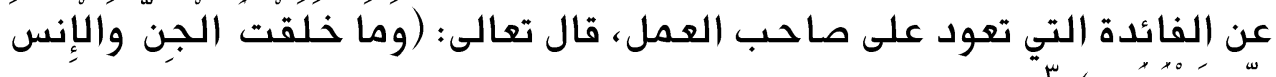
فمفهوم العبادة في الشـريعة واسع ورحب، لإيقتصر على الصلاة والصيام والحج وغيرها، بل إن جميع الأعمال والحرف التي يتوصل بها الإنسان أو بشيء منها إلى القيام بواجبات النفس أو من

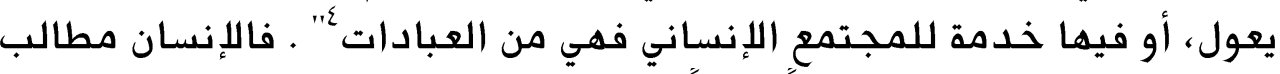

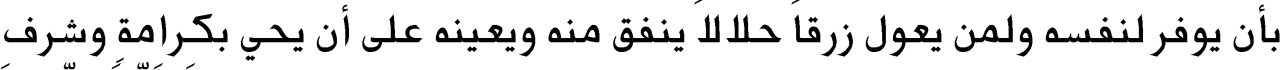

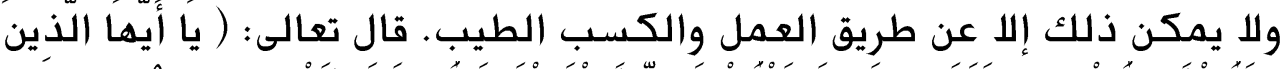

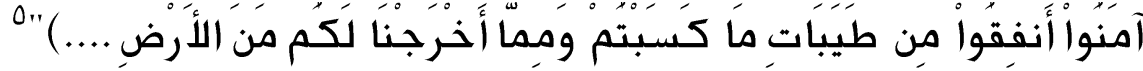
والعبد المؤمن الذي يسعى للكسب الحلال من عمله يرتقي بذلك لدرجة

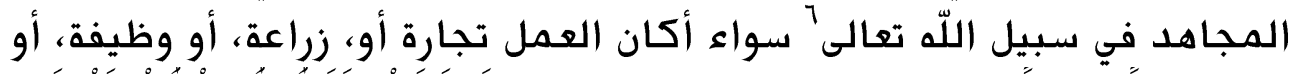

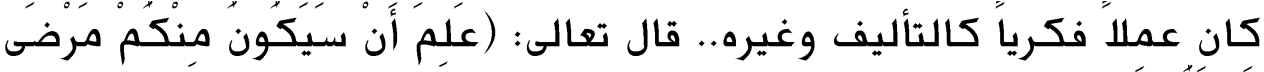
وَّآخرون

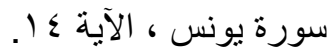

سورة التوبة الآية:0 ـ الآنه

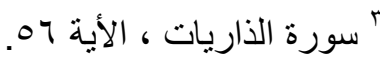
؛ انظر أحكام الحرفة و أثرها في الفقه الإسلامي ، الثيخ عزيز الضزي ، ص ه هـ مرجع سابق.

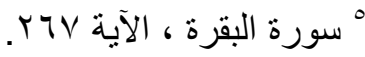

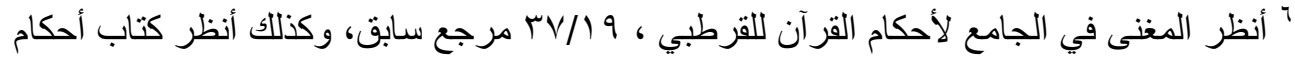

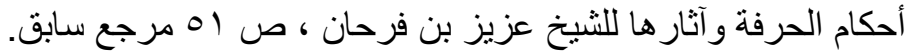




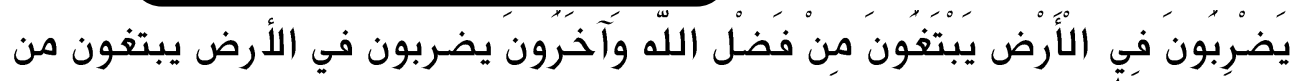
فضل اللّه)

ففي حديث كعب بن عجرة رضي اللّه عنه، قال: " مرّ على النبي صلّ صلى اللّه عليه

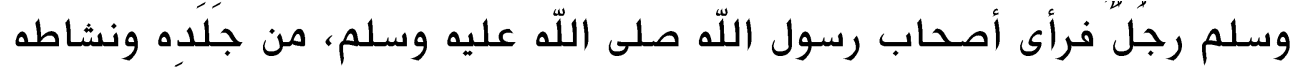

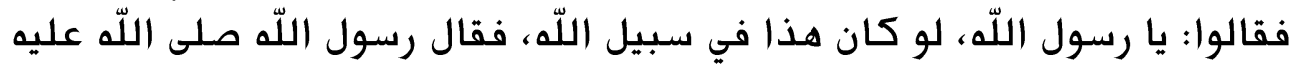

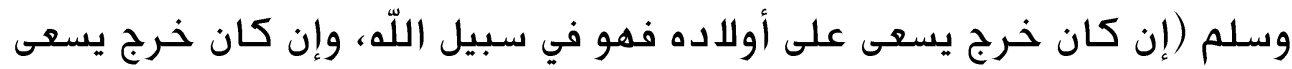

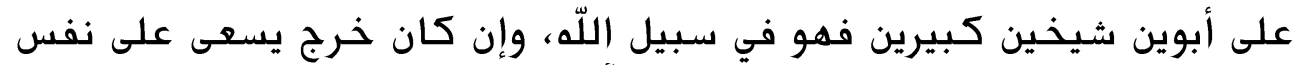

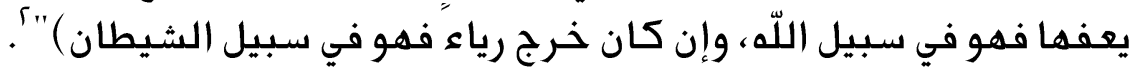

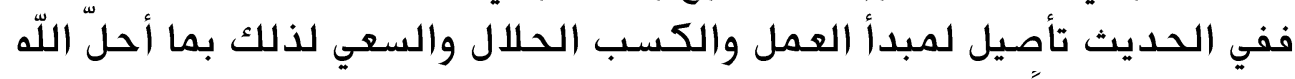
تعالى، استشرافا لمرضاته سبحانه.

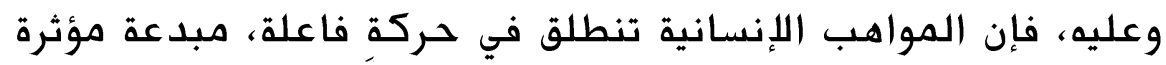

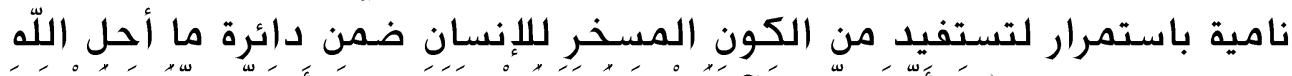

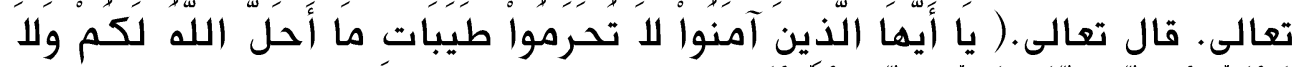

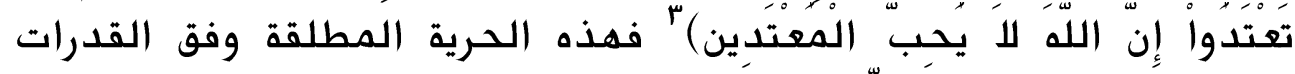

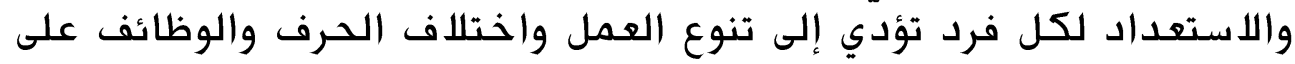

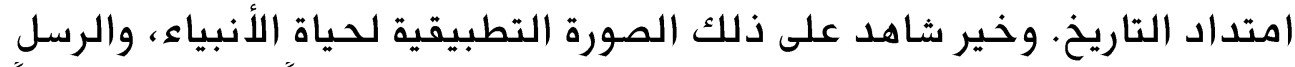

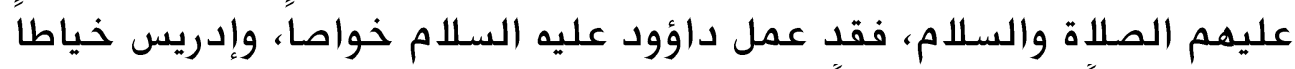

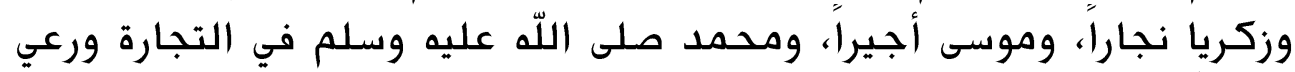

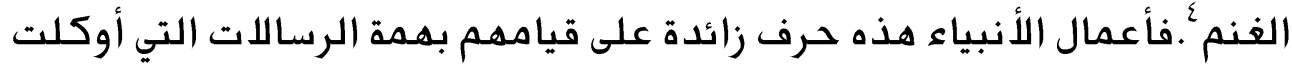

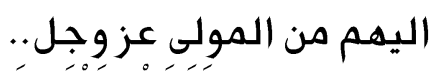

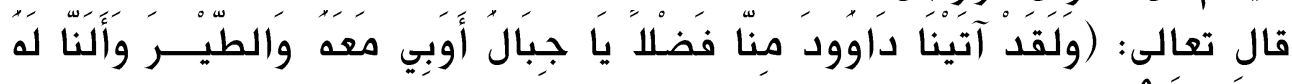

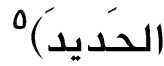

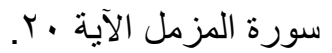

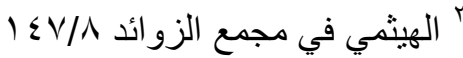

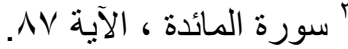

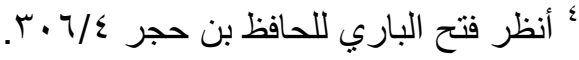


المطلب الثاني : منهجية الرسول صلى الله عليه وسلم في الدعوة الإتقان

لم تجد البشرية منهجاً أصلح مما رسمه القرآن الكريم وبينه نبيه صلى الله عليه

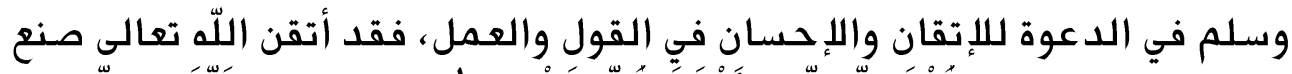

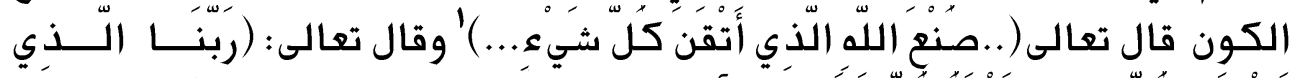

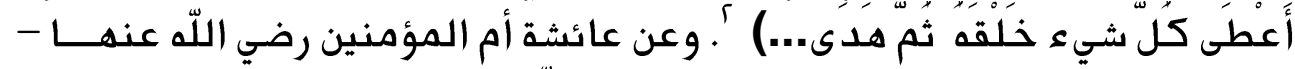

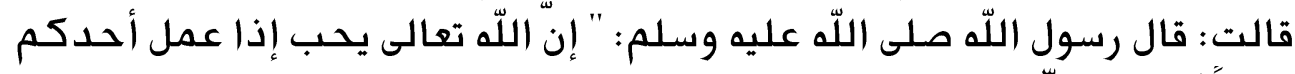

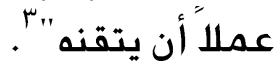

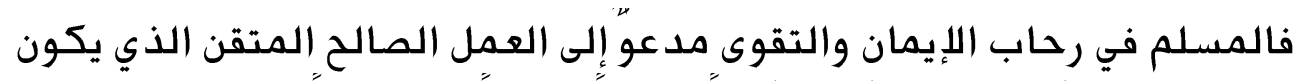

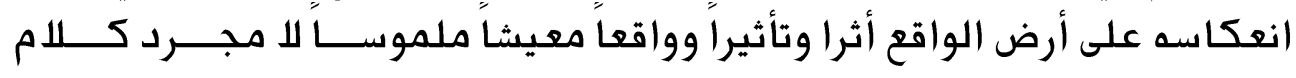
ونصائح تسدى هنا وهناك.

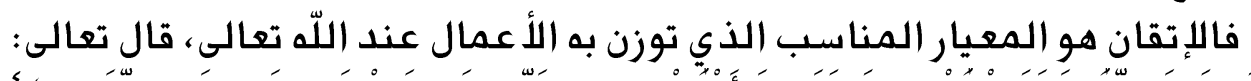

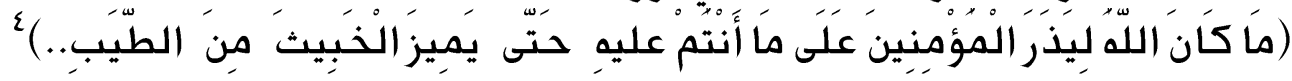

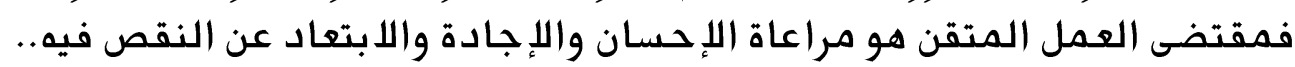

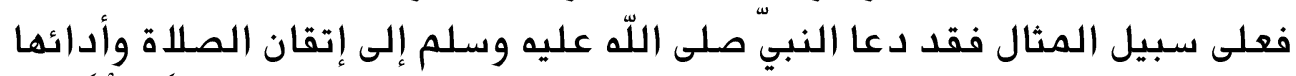

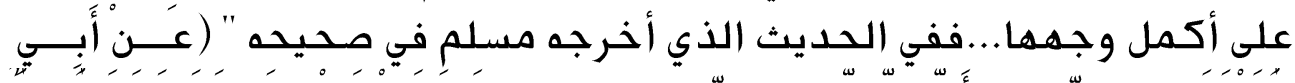

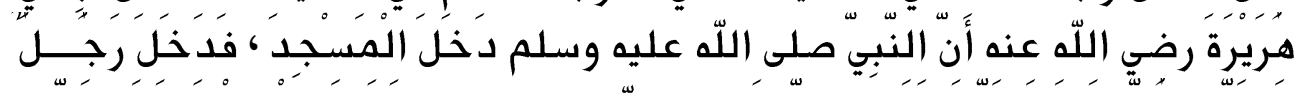

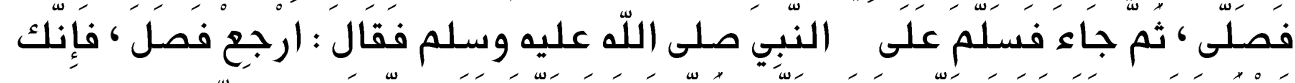

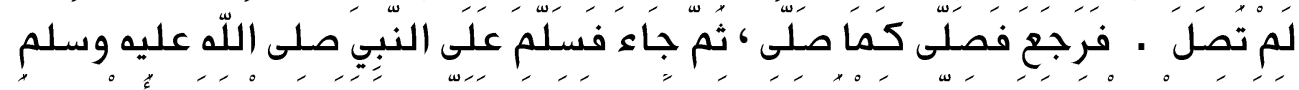

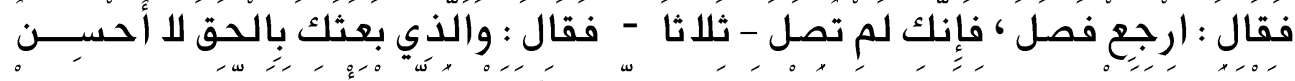

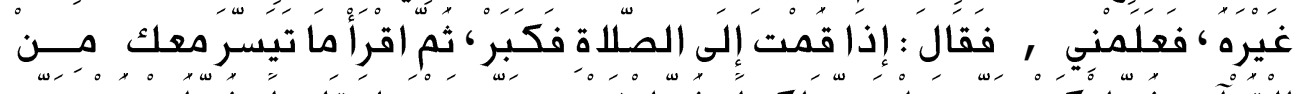

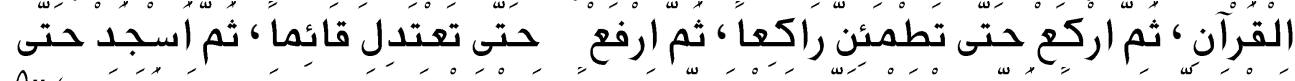

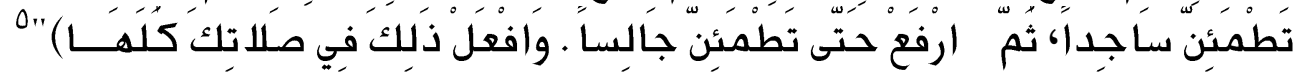

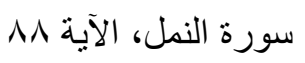

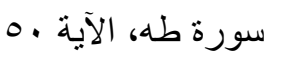

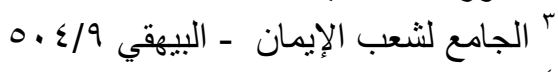

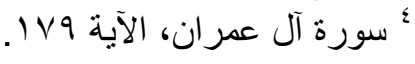

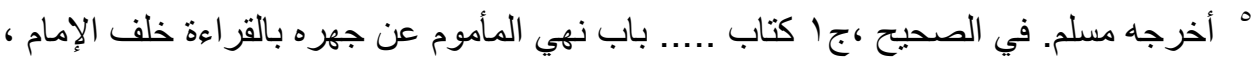


ففي هذا الحديث توجيه بإتقان الصلاة وإكمالها على أحسن الأحوال والاجتهاد

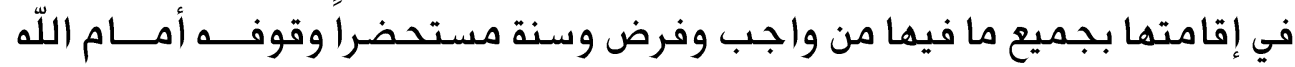

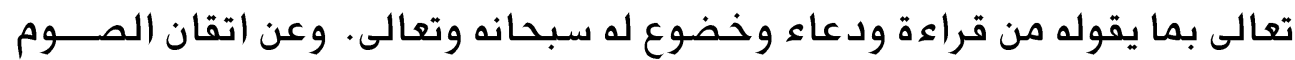

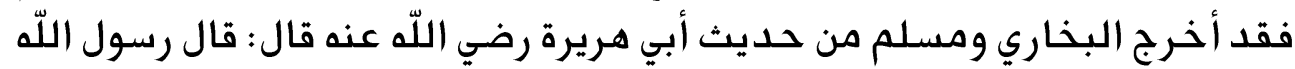

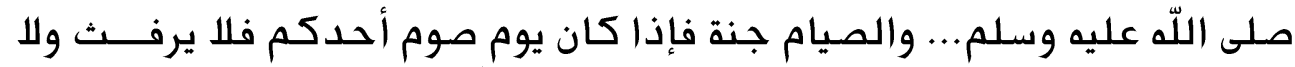

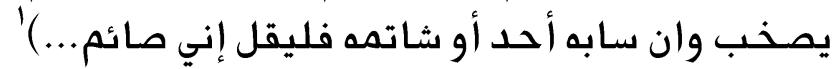

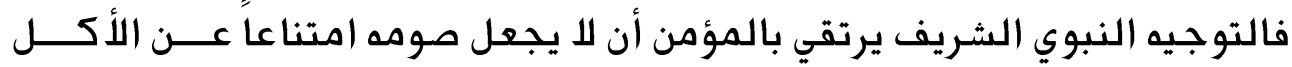

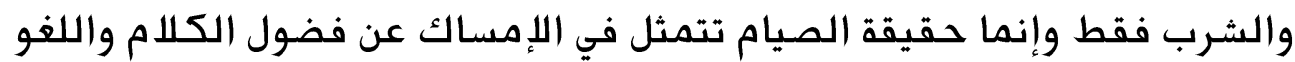

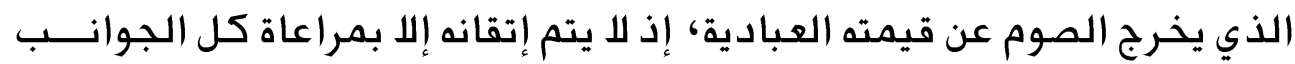
العبادية والسلوكية والأخلاقية.

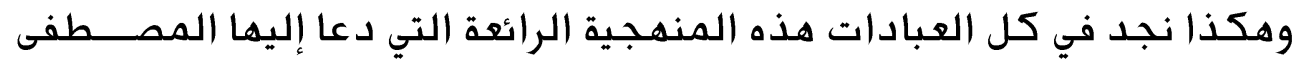

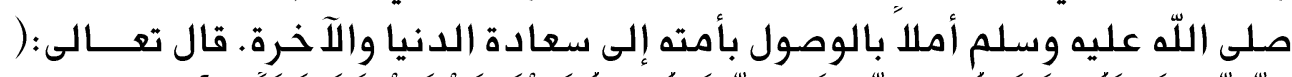

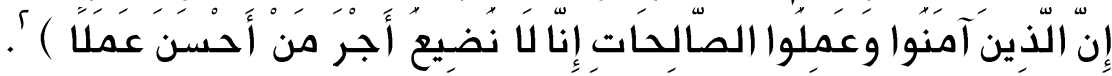

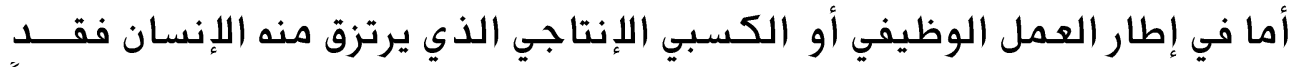

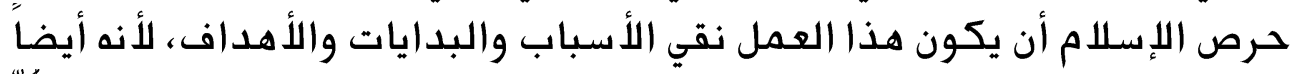

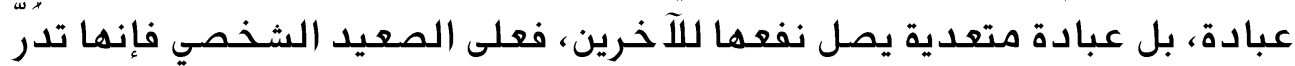

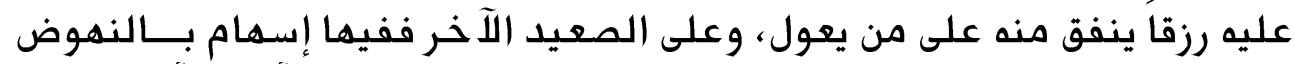

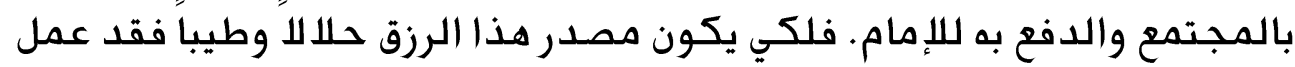

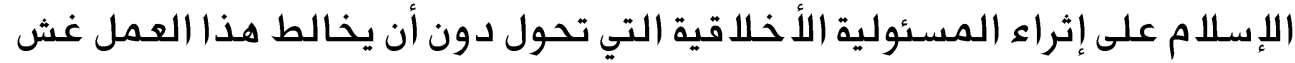

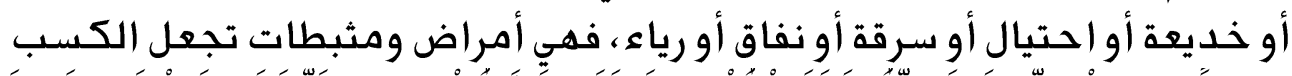

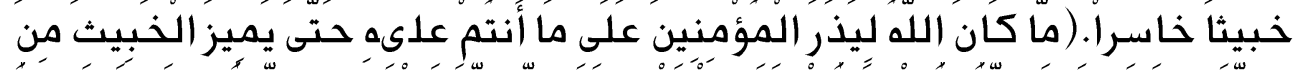

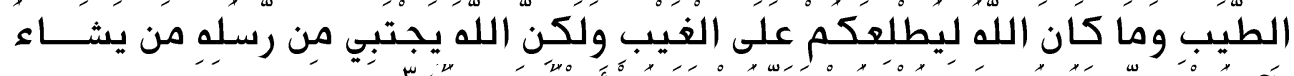

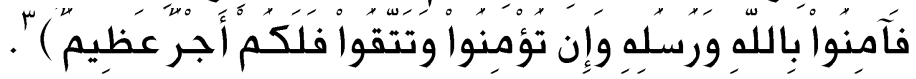

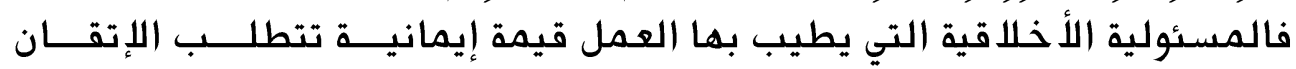

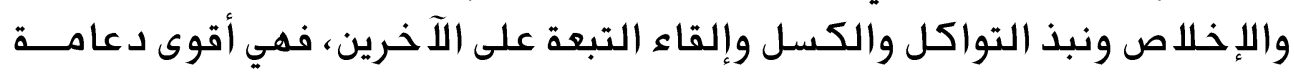

11.0 ا ترقيم مصطفى ديب أخرجه البخاري في كتاب الصوم ،باب 


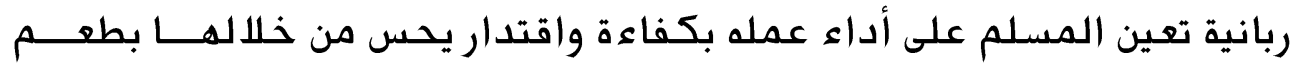

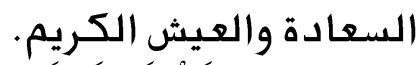

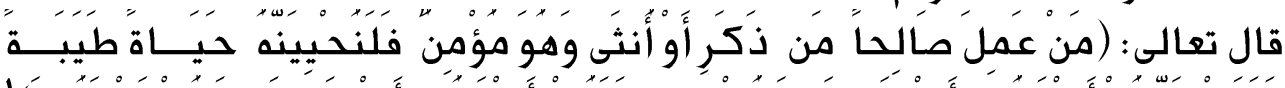

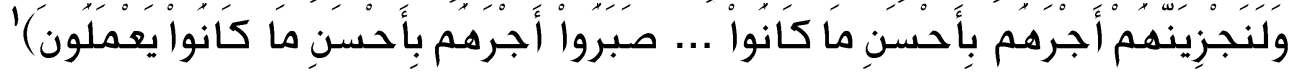




\section{المبحث الثالث : ضوابط المائولية الأخلاقية في المهل}

المطلب الأول: محاسبة النفس:

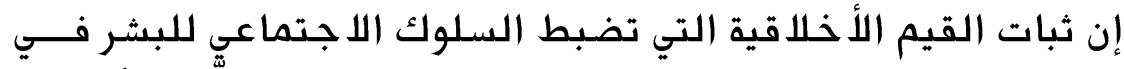

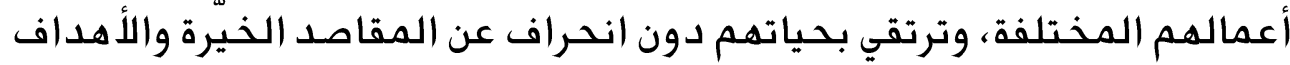

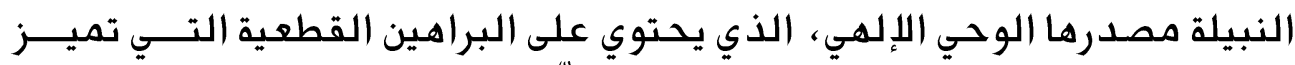

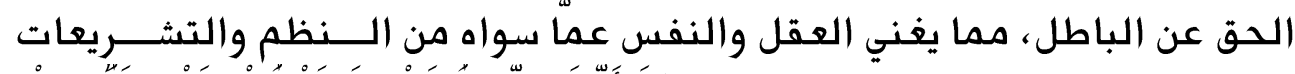

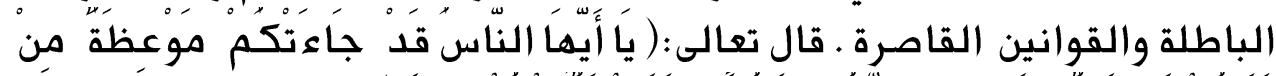

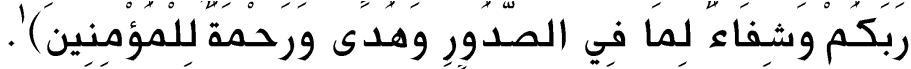

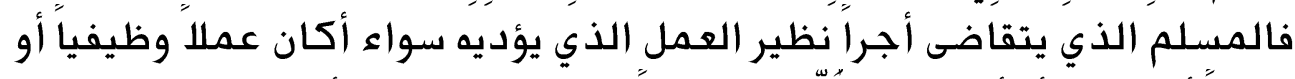

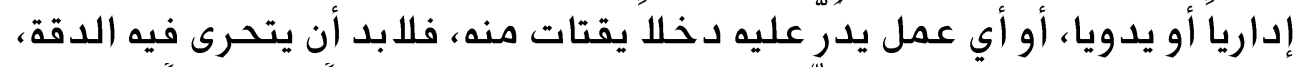

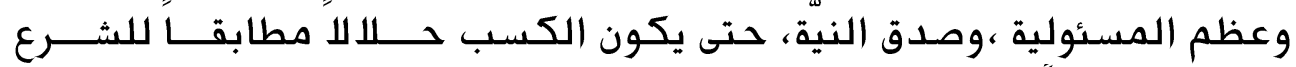

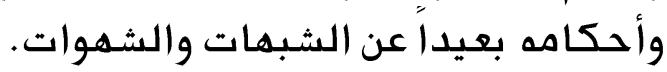

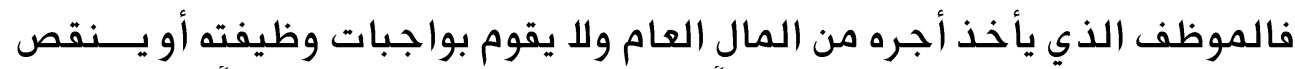

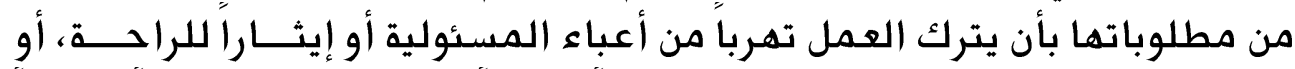

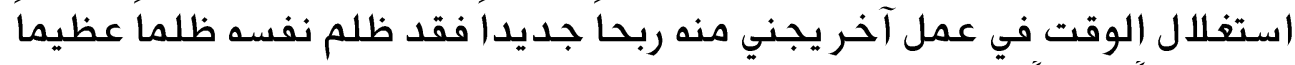

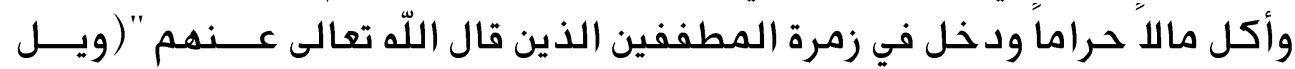

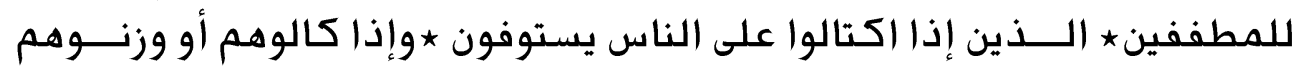

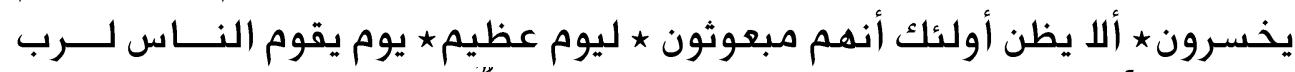

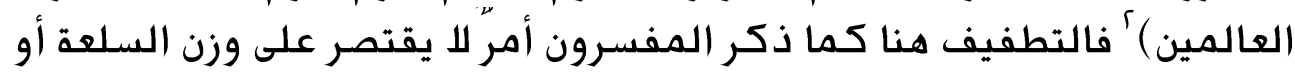

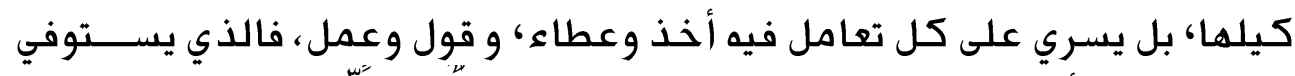

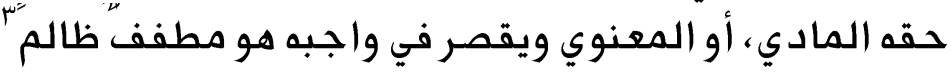

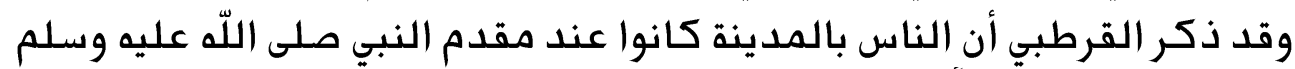

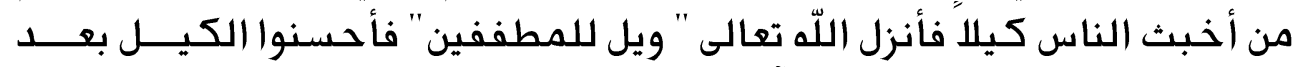

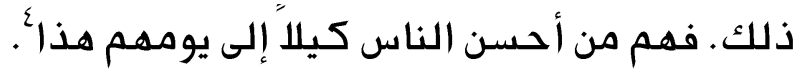

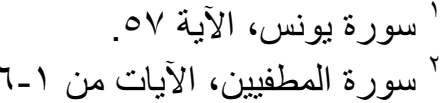

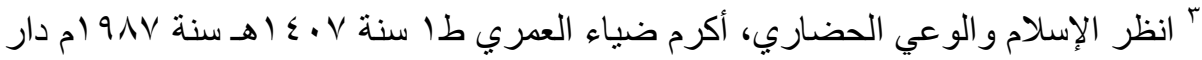

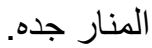




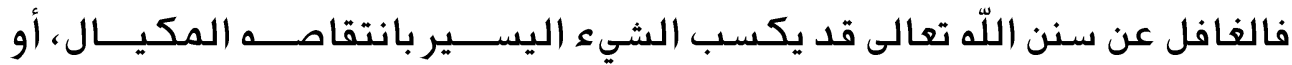

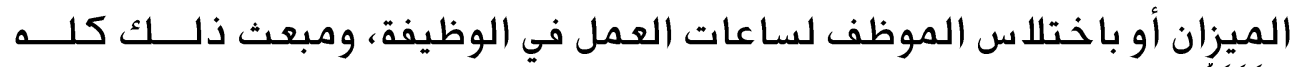

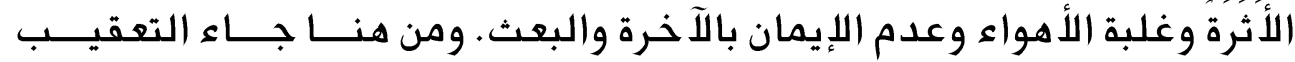

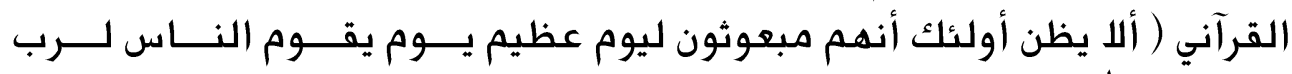

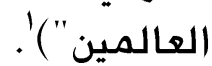

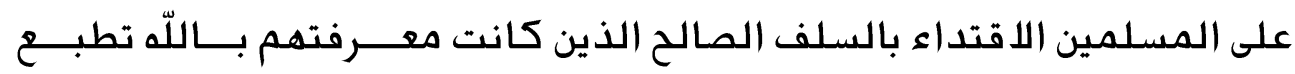

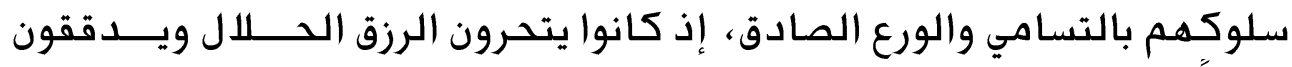

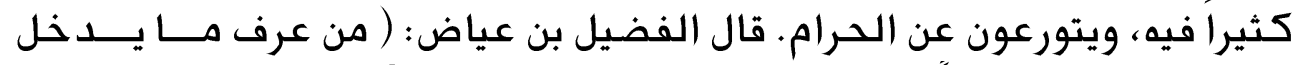

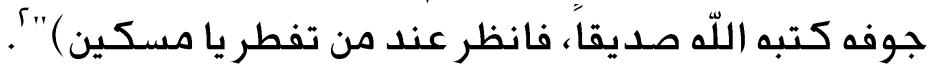

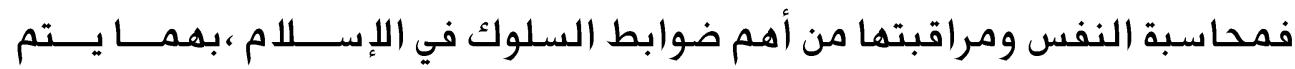

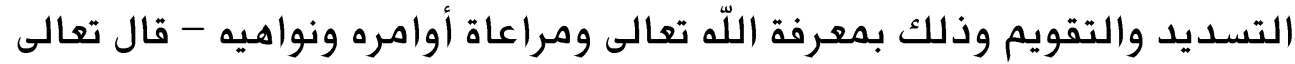

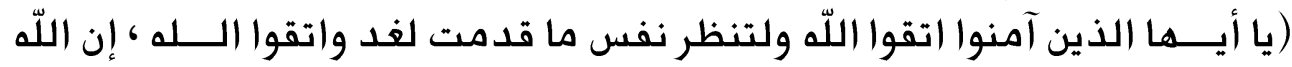

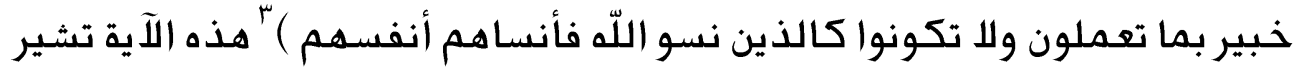

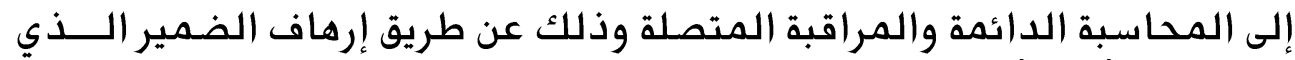

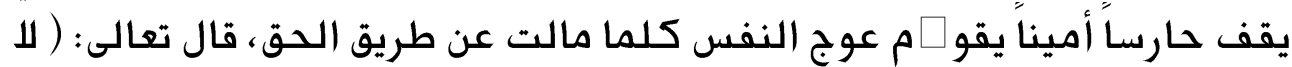

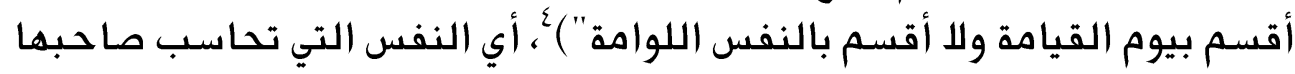

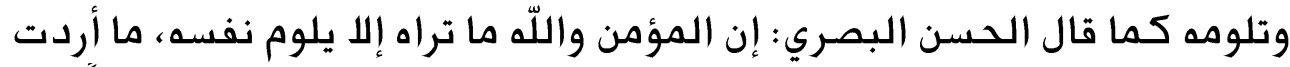

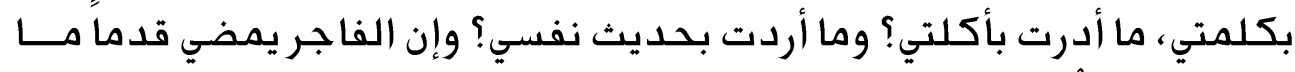

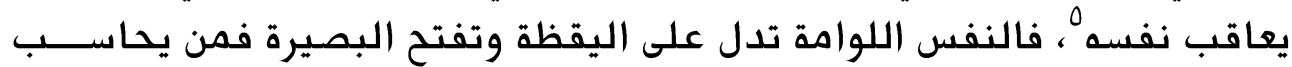

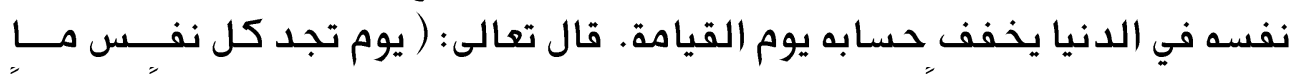

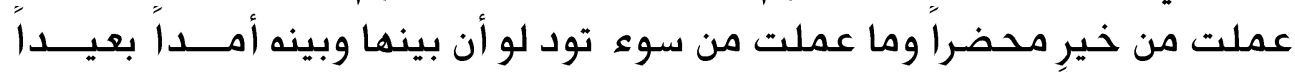

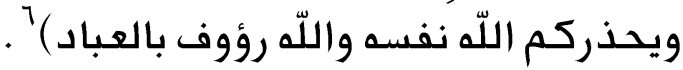

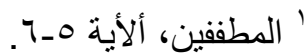

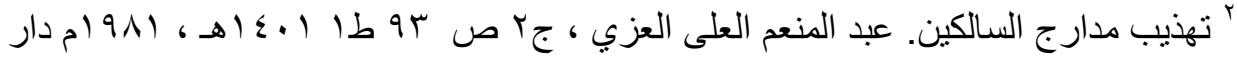

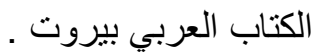

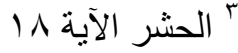

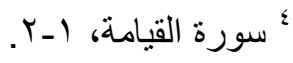

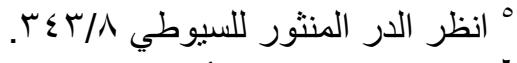

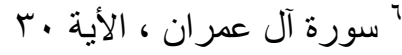


يقول سيد قطب " إنها اللارتعاشة الوجدانية التي تنتاب القلب المؤمن حيث يذكر

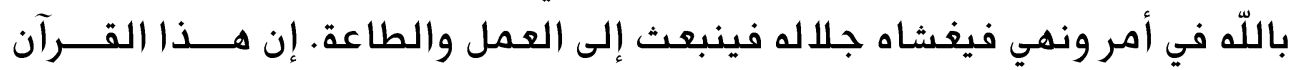

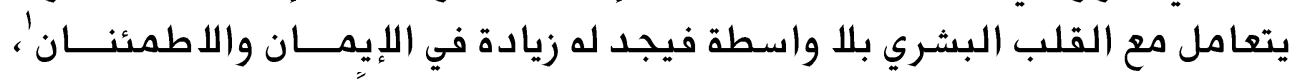

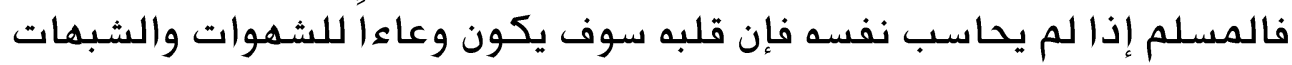

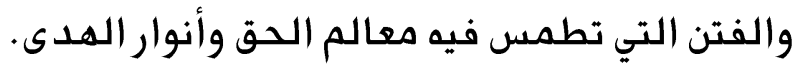
قال الشاعر:

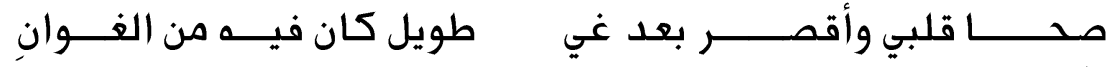

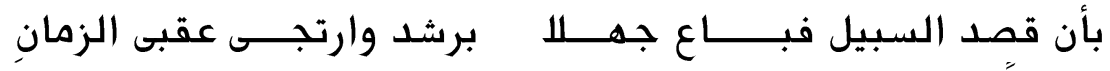

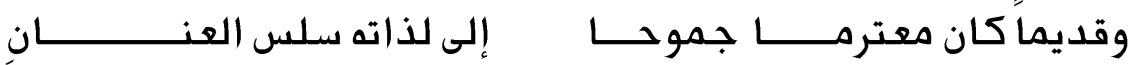

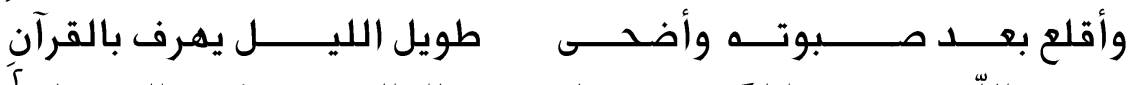

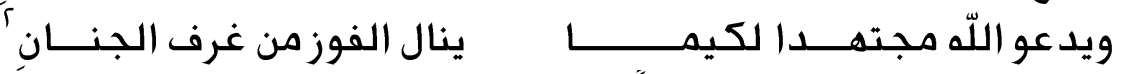

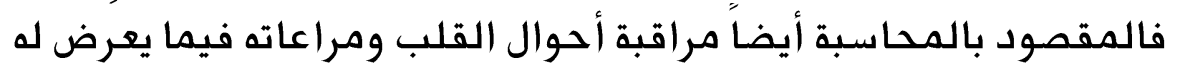

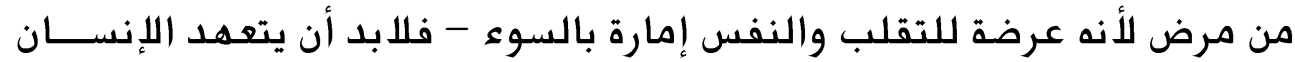

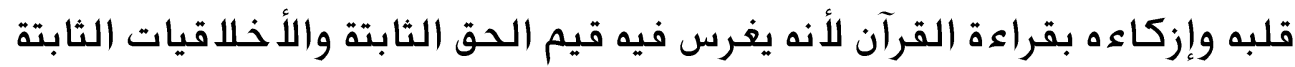
والمثل العليا. بهذه المحاسبة تسمو نفس المسلم وتترفع عن كل دنيئة ويطيب كسبه

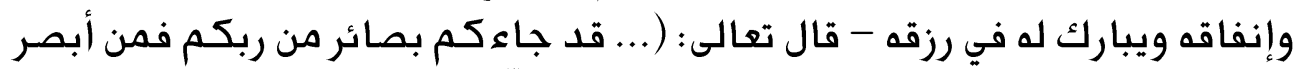

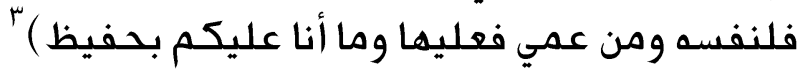

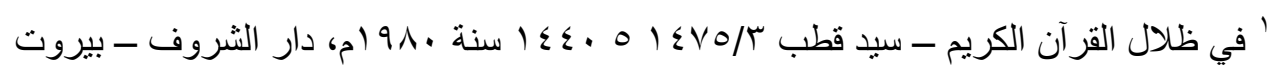

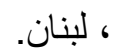

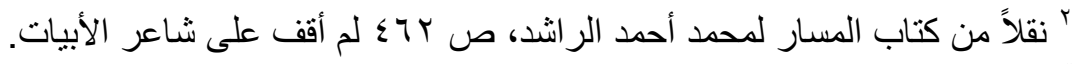


المطلب الثاني : الأمانة واستشعار عظمها الأمانة من أخلاق المسلم التي تدل على استقامة فطرته وأصالة صدقة والمه واتجاهه،

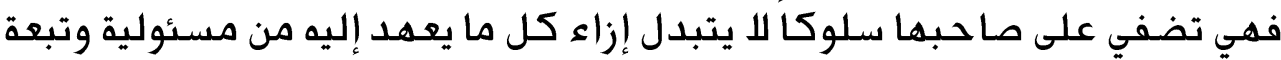

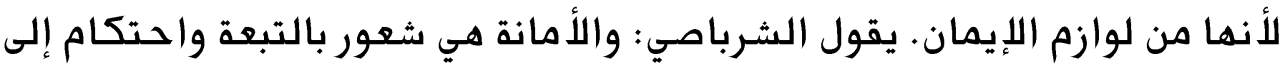

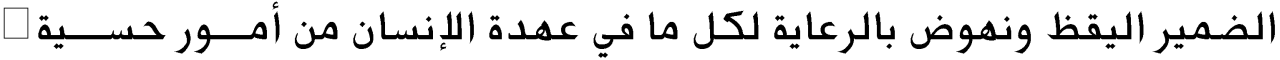

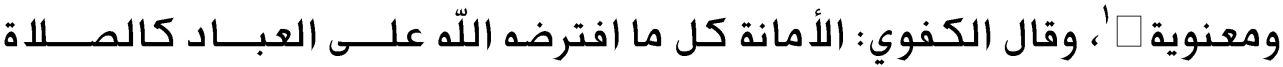

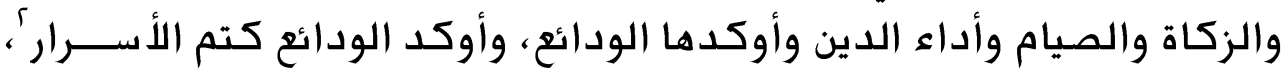

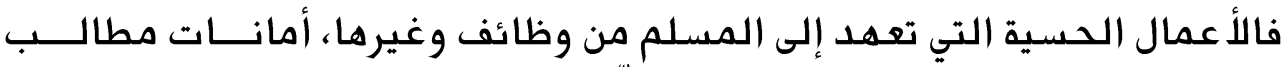

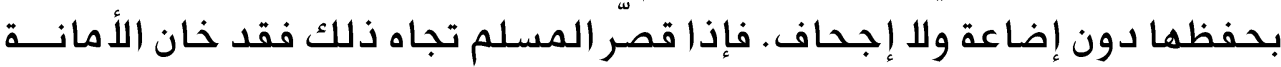

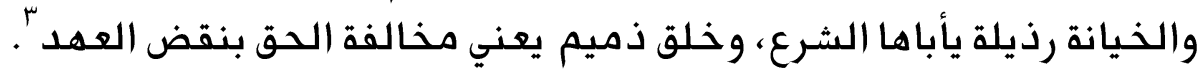

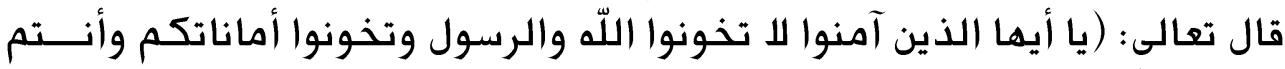
تعلمون) تعال تعالع

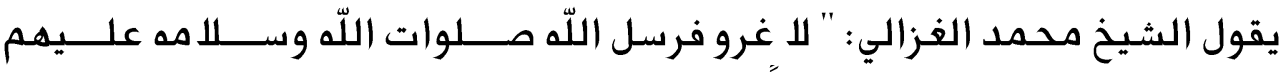

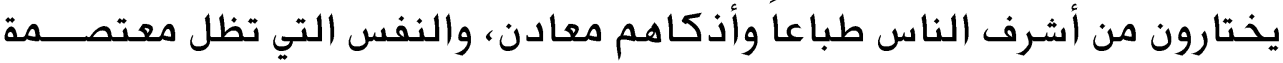

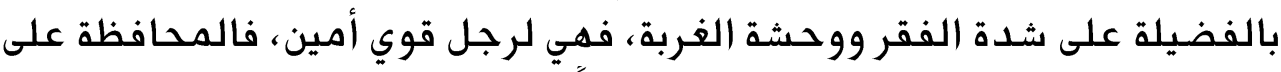

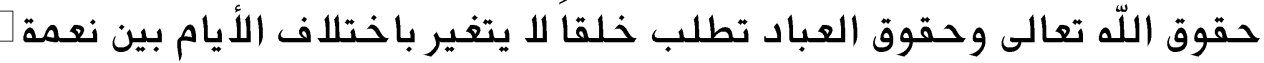
وبؤس $\square$ وذلك جوهر الأمانة.

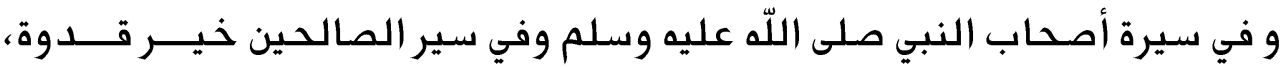

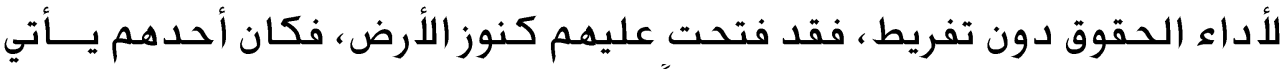

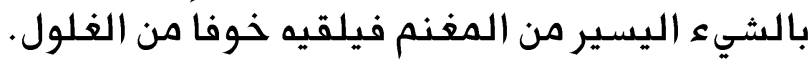
ومن ثم يتضح عظم الأمانة في قول النبي صلى اللّه عليه وسلم لحيلم لحذيفة بن اليمان:

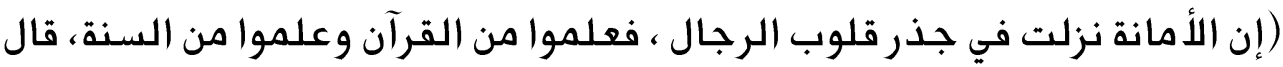

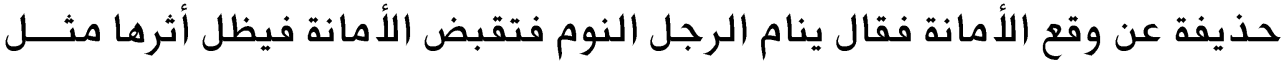

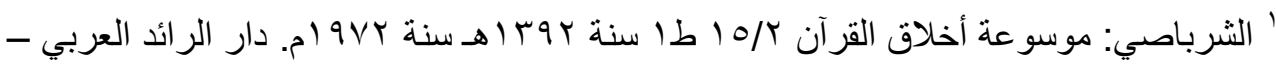
بيروت - البنان.

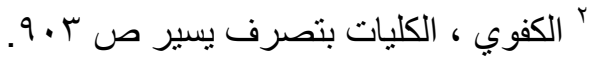

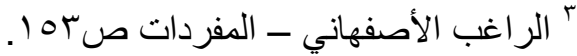

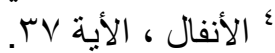

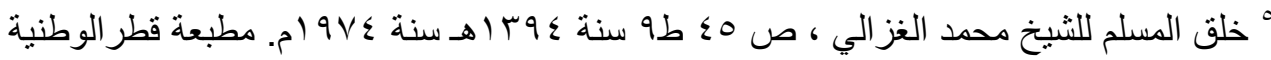


الوكت ،ثم ينام فيظل أثرها مثل المجل إلى أن قال ..فيصبح الناس يتبايعون فلا

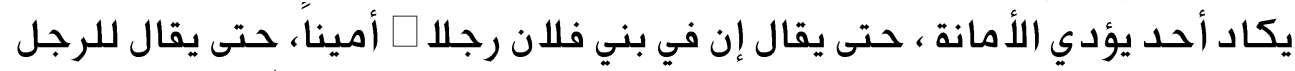

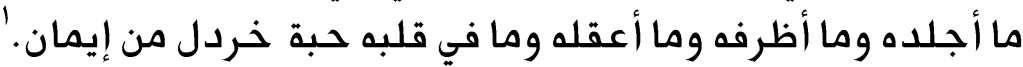

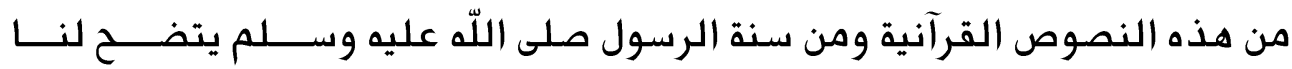

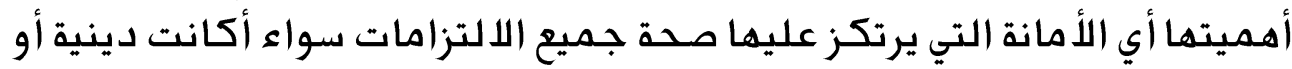

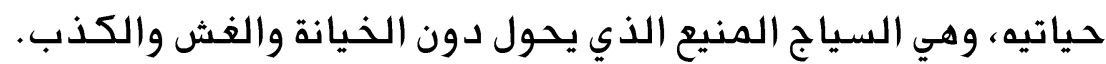

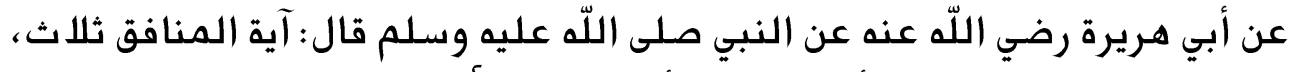

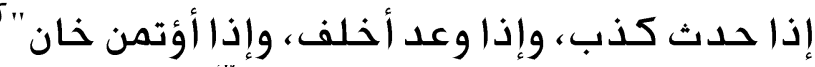

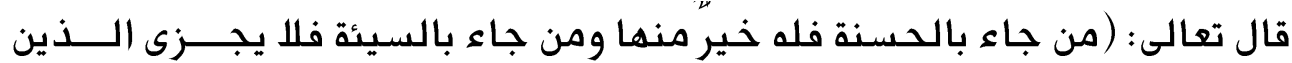

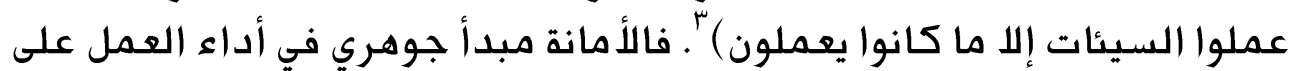

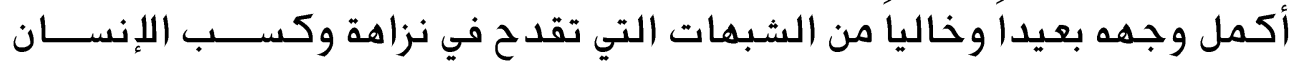

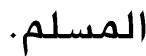

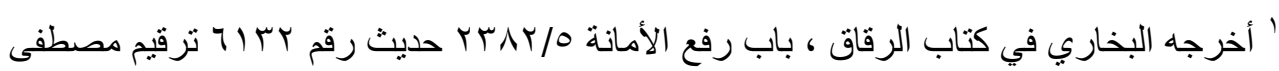
ديب البغا مرجع سابق الخماري

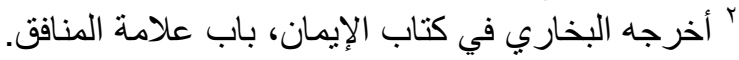

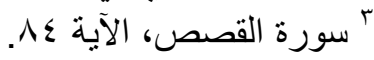




\section{المبحث الرابع ـ أسس الإنقان}

المطلب الأول: الإخلاص والتجرد

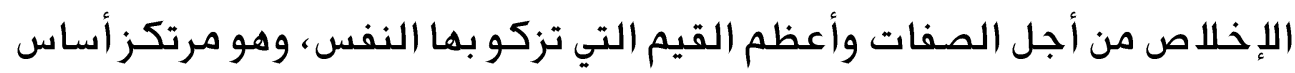

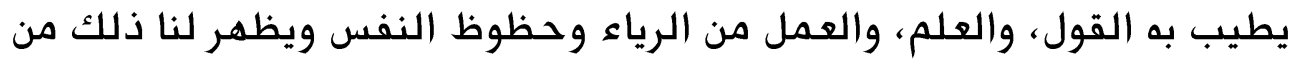

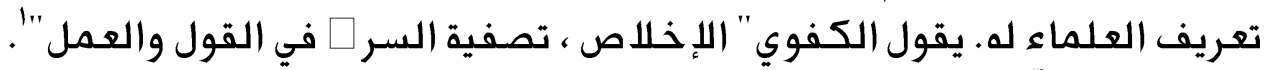

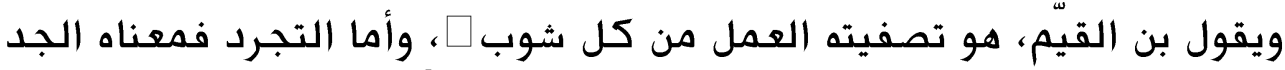

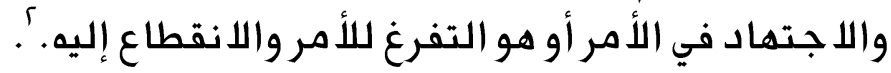

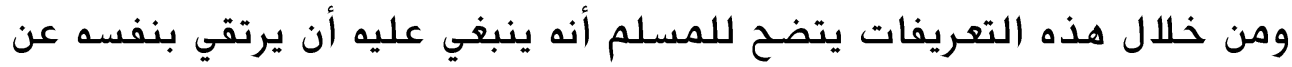

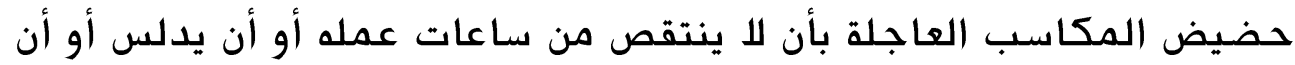

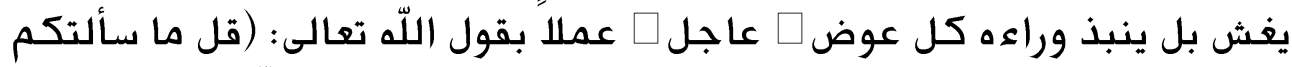

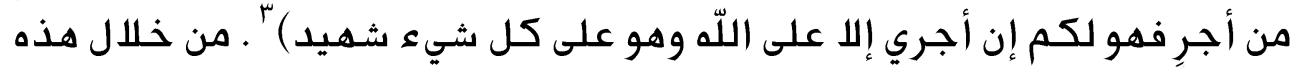

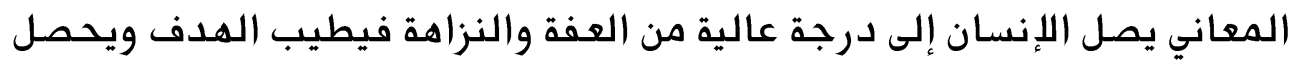

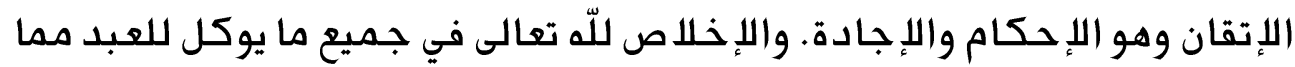

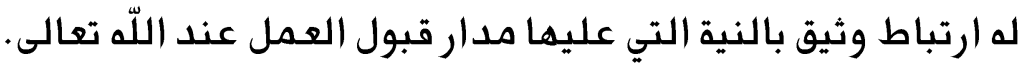

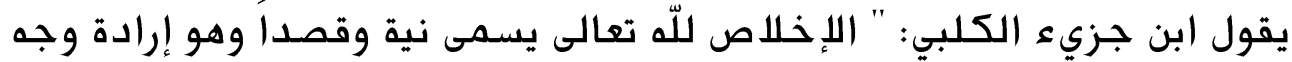

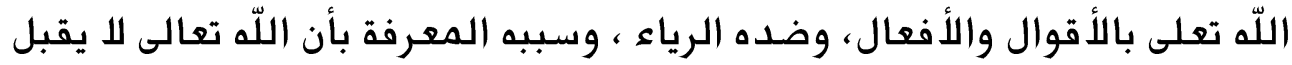

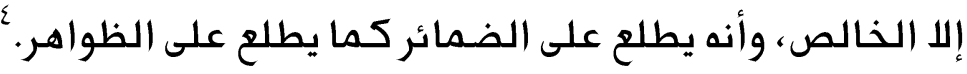

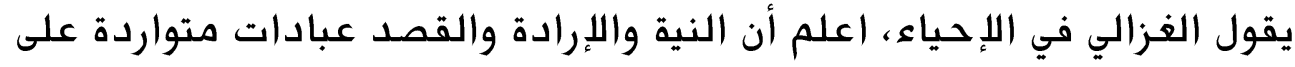

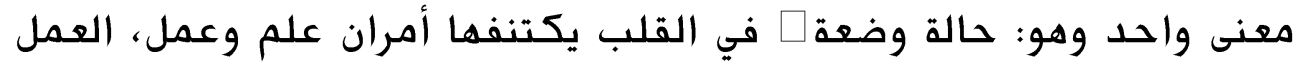

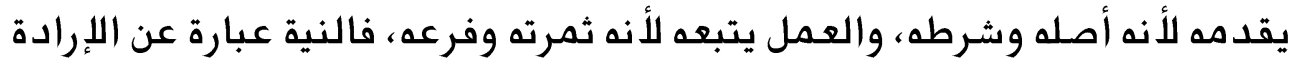

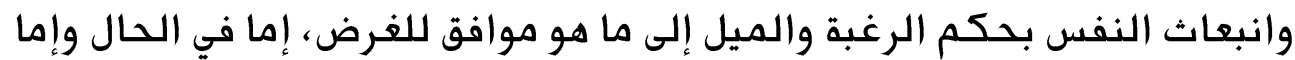

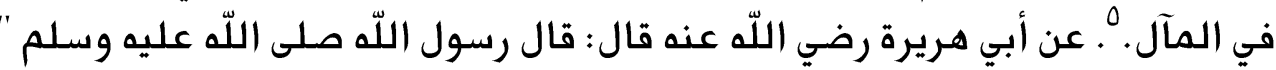
إن الله للا ينظر إلى أجسامكم ولا إلى صوركم ولكنه ينظر إلى قلوبكم

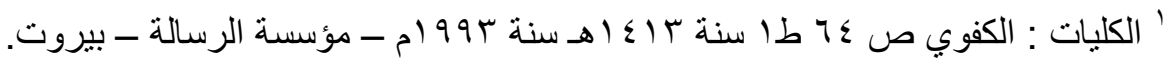

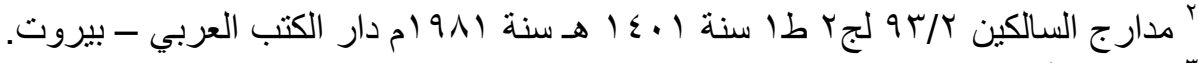

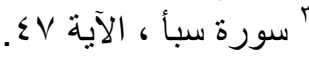

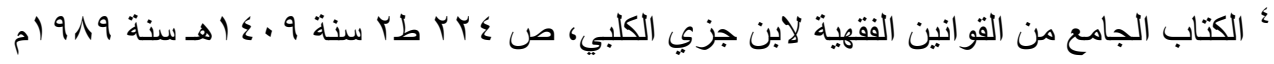

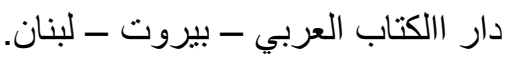


وأعمالكم".' فهذه الأقوال توصلنا إلى موازنة دقيقة، و تقودنا إلى إتقان أعمالنا

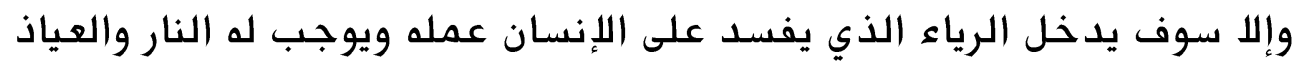

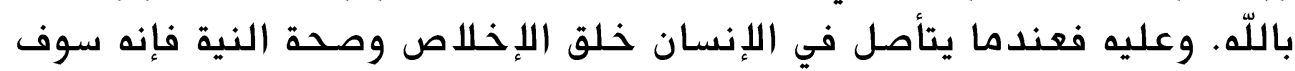

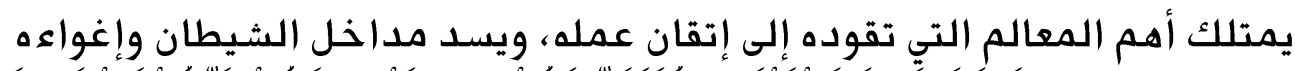

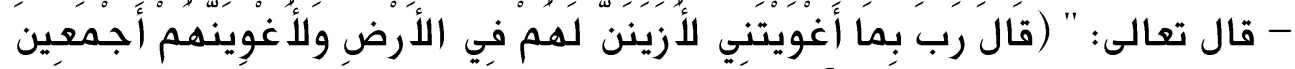

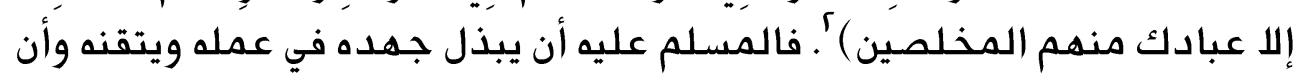

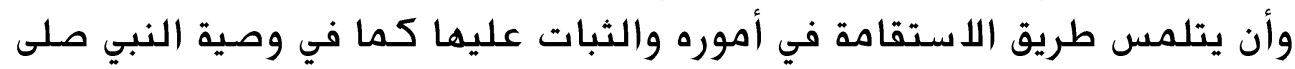

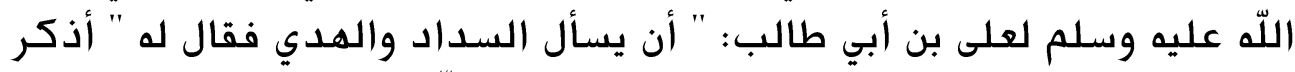

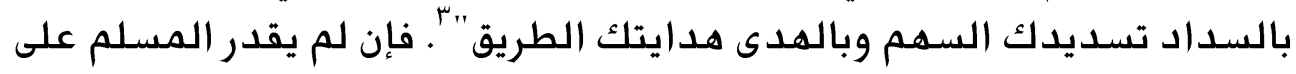

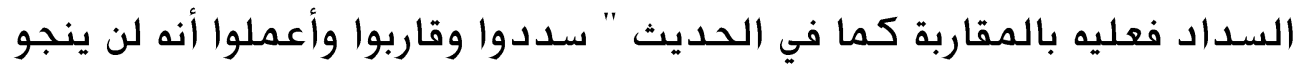

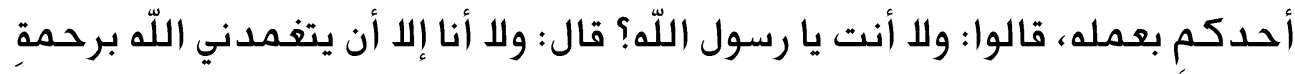

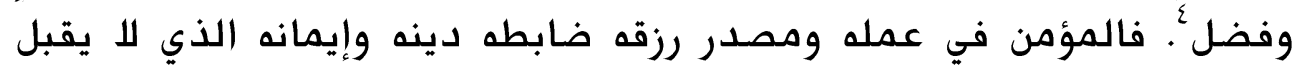

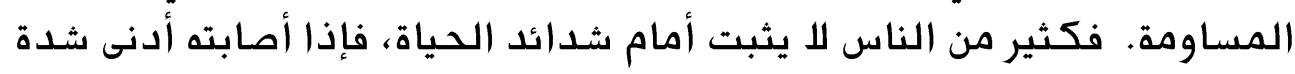

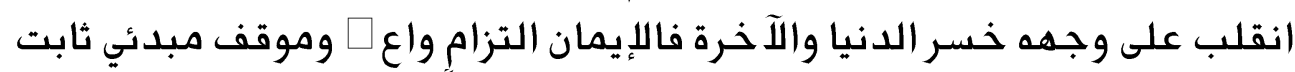

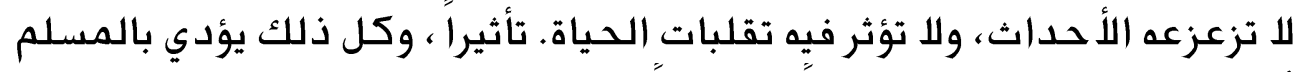

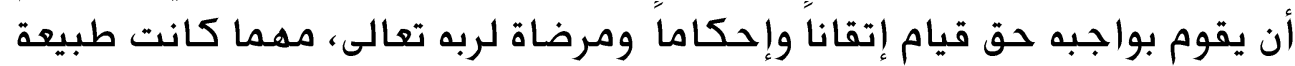

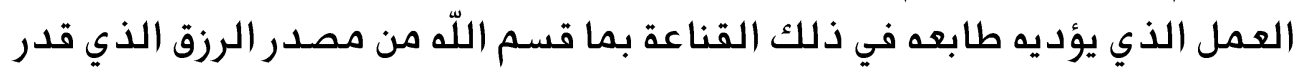
له من غير تبرم ولا سخط.

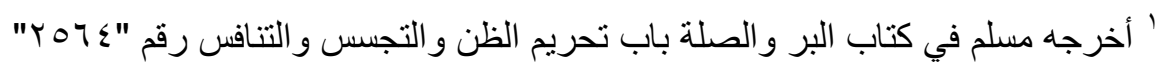

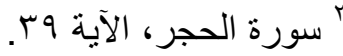

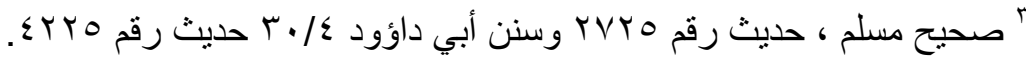

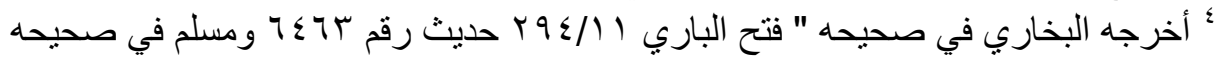


المطلب الثاني : الصدق في تجويد المهنة:

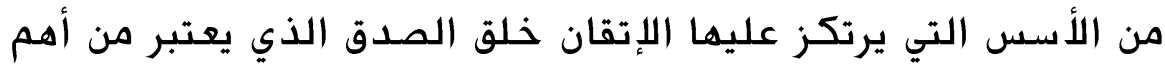

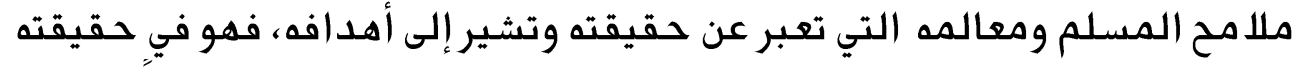

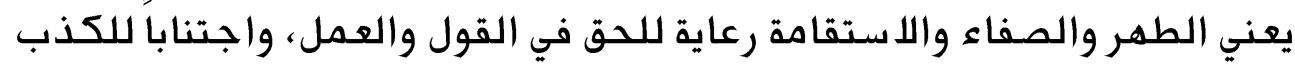
الذي بمحق البركة ويفسد الحياة.

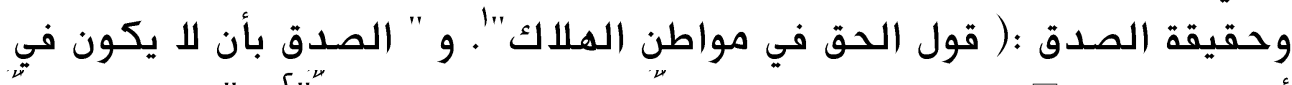

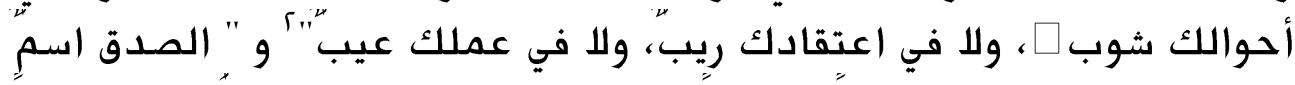
لحقيقة الشيء بعينه حصولا ووجودا، حصول الشيء وتمامه عزيمة وليمة صاد عقة وقوة تامة.

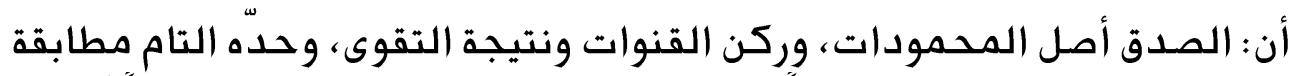

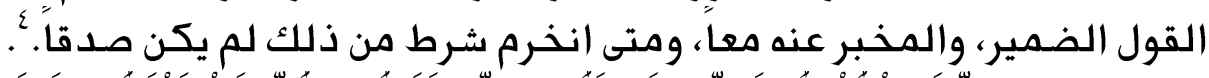

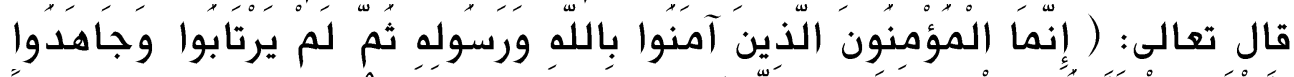

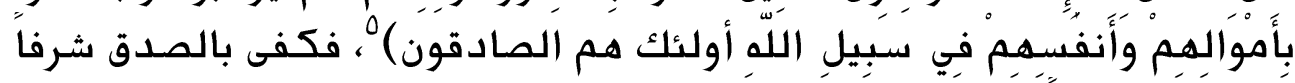

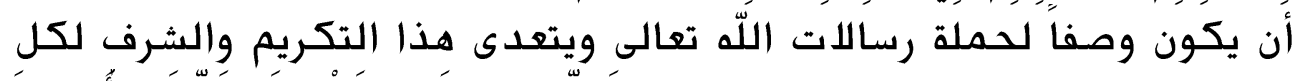

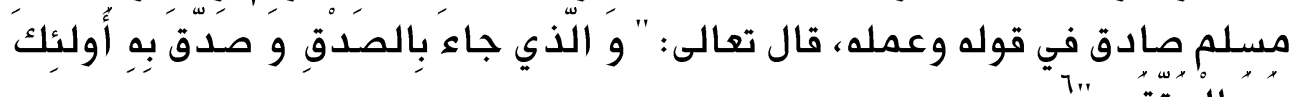

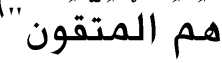
يقول السعدي: " دخل في ذلك الأنبياء ومن قام مقامهم ممن صدق فيما قاله من

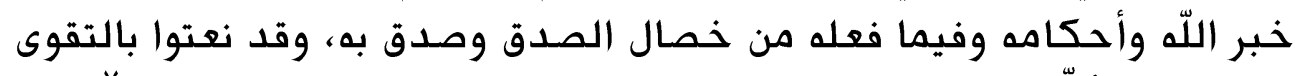

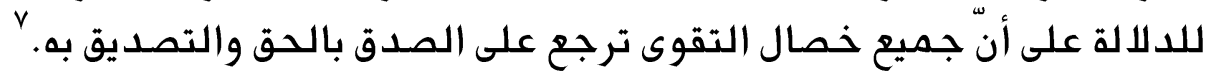

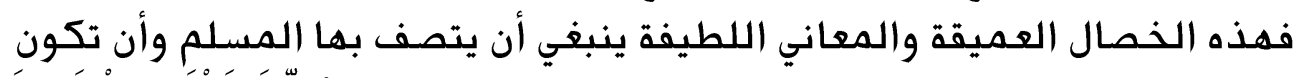

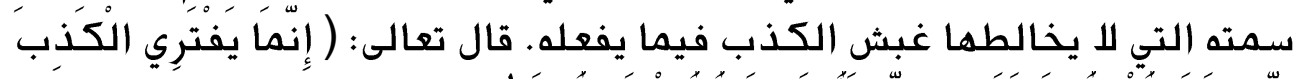

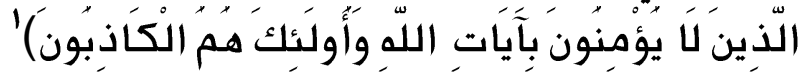

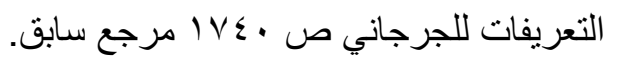

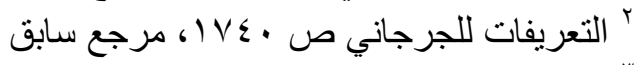

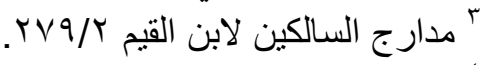

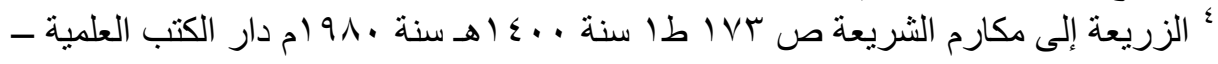

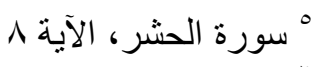

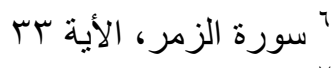


فالكذب ضد الصدق وهو كبيرة ممقوتة وذلك وعار للازم ينتفي معه السداد في

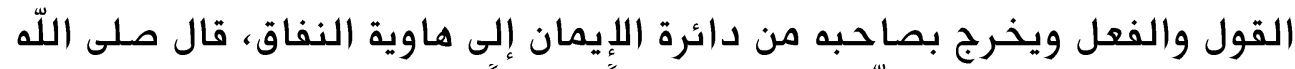

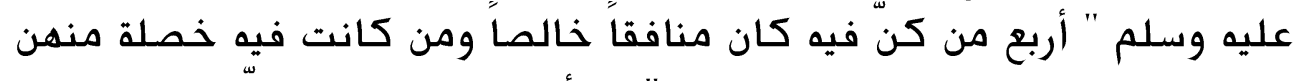

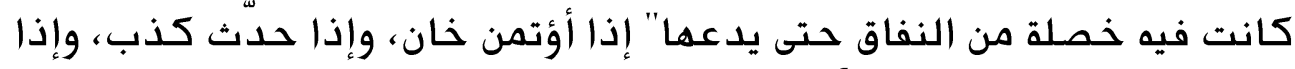

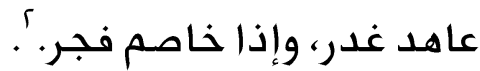

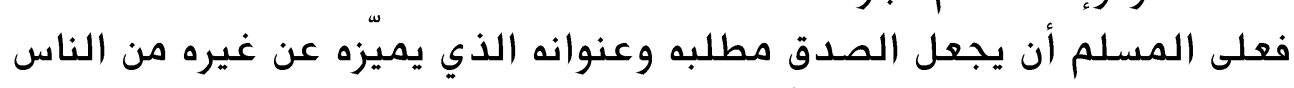
حتى يطيب العمل والكسب والأجر. 


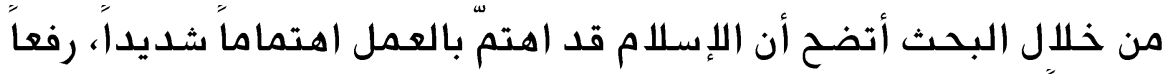

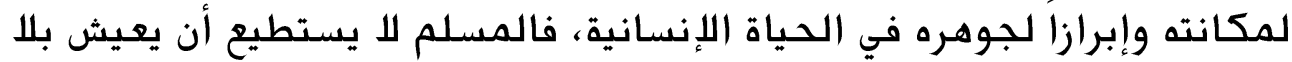

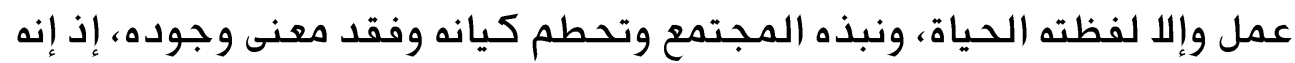

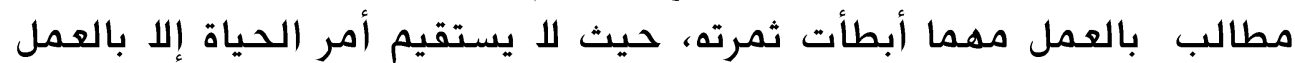

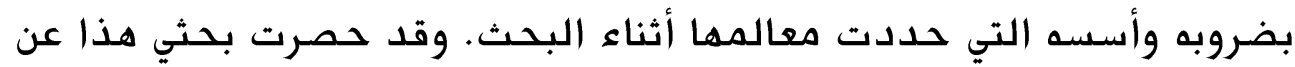

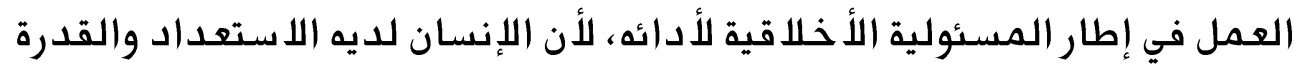

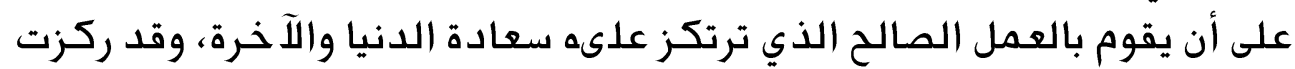

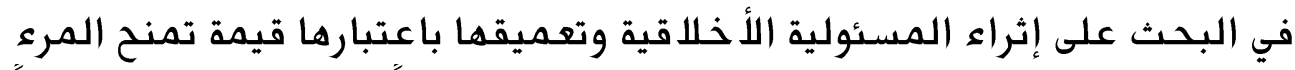

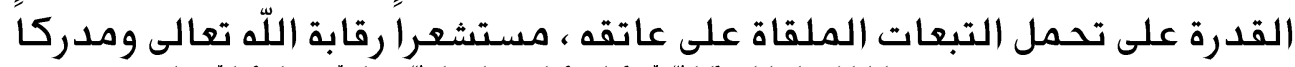

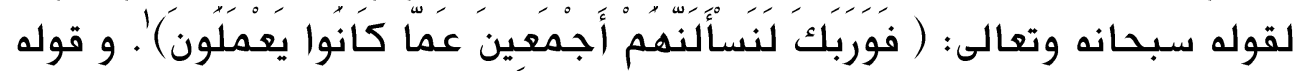

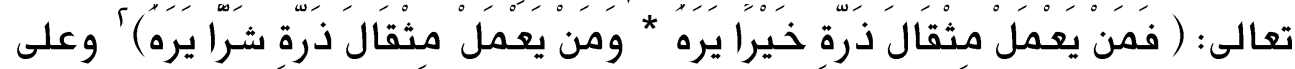

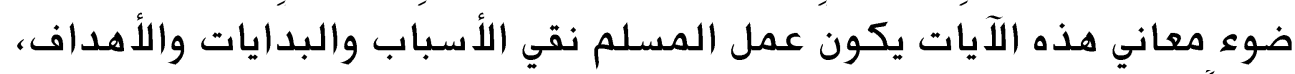

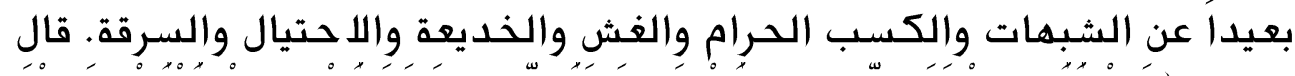

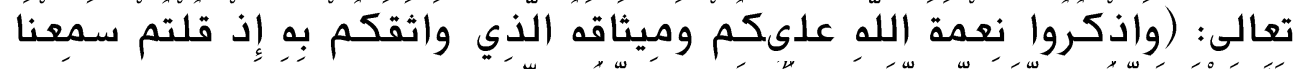

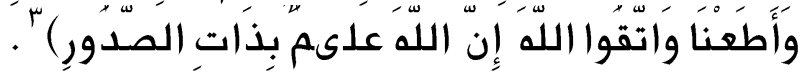

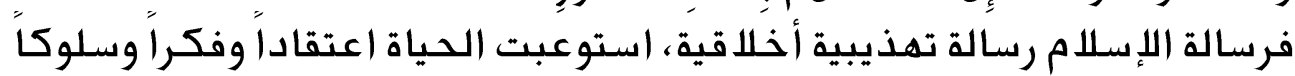
بأسس قوامها اللاستقامة على منهج الله تعالى، وعلى ضوئها ينتقي الإنسان الذان عمله الذي يربطه بربه عبودية خالصة ومن ثم يضبط عمله الذي يرتزق منه ويكون

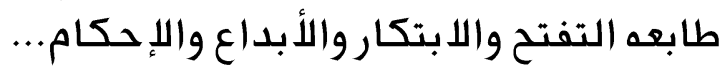




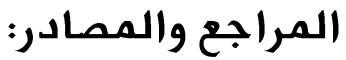

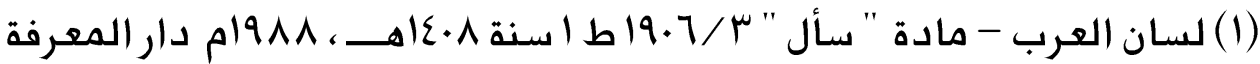

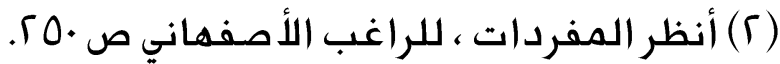

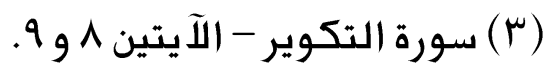

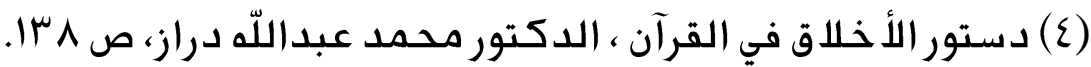

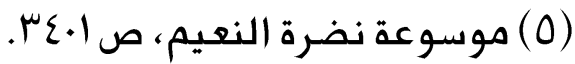

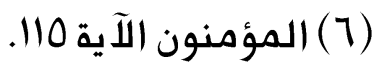

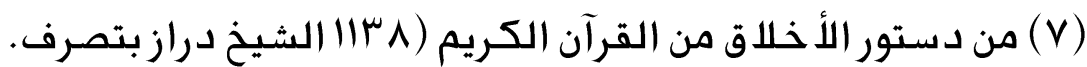

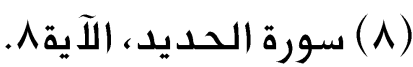

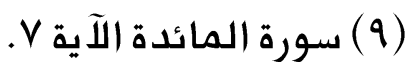

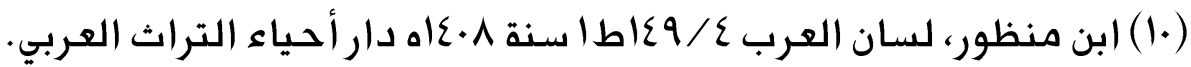

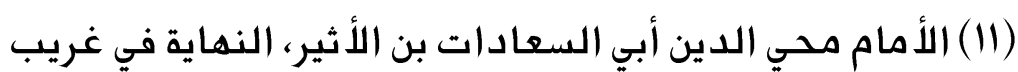

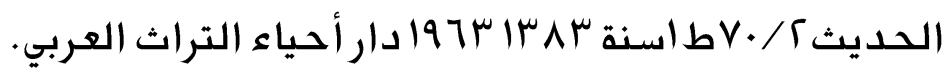

(זI) الدكتور ناصر بن عبد اللّه التركي ، الفساد الخلقي في المجتمع وأسبابه ص ا طا سنة س.. ام - الشئون الإسلامية والأوقاف الرياضي.

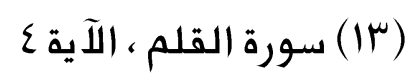

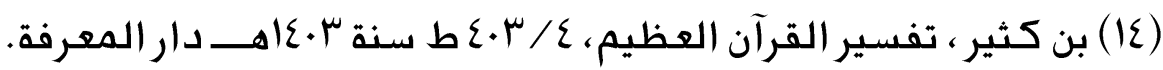

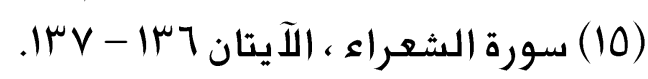

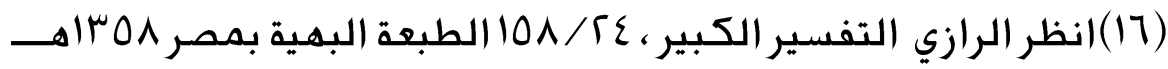
(الإمام الغزالي ، إحياء علوم الدين س/ (IV)

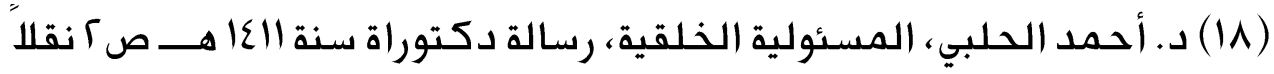
عن كتاب الفساد الخلقي للدكتور ناصر التركي ص VI V مرجع سابق.

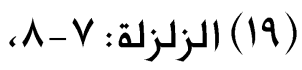

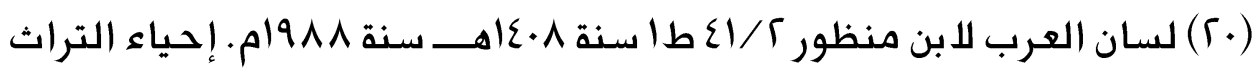
العربي - بيروت لبنان، تحقيق على سيرين 
(آ) أنظر اللباب في علوم الكتاب، عمر بن على الدمشقي الحلبي 10/7 ·؟ طا

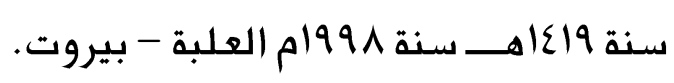

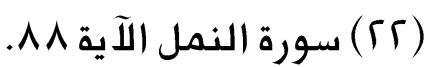

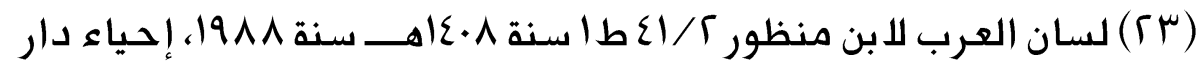
التراث العربي - بيروت لبنان، تحقيق على شيري.

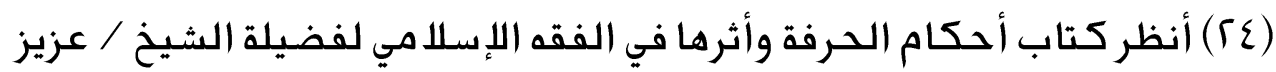

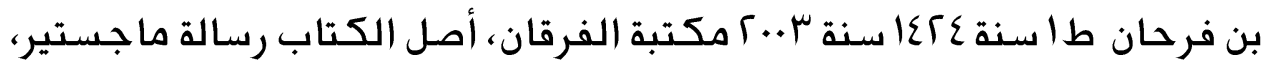
البحث مطول ومفيد لكل طالب علم في هذا المجال.

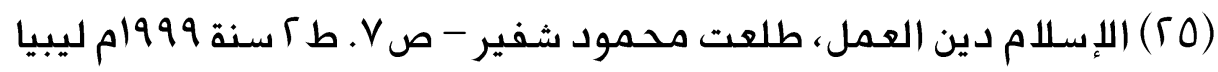
جمعية الدعوة الإسلامية العالمية - طرابلس.

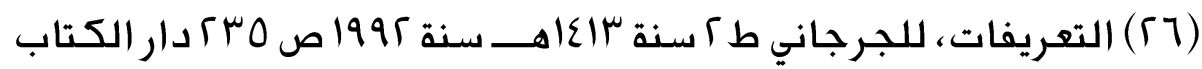
العربي بيروت لبنان. (TV) أنظر أخلاقيات الوظيفة العامة، د. عبد القادر الشيخلي ط 1999 دام دار

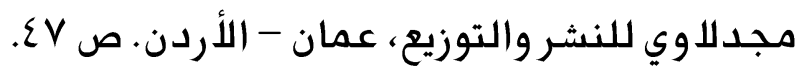

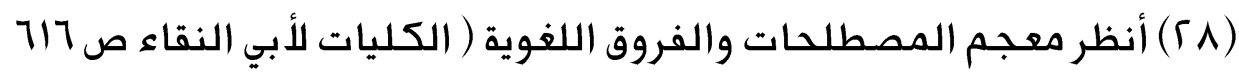
طا سنة كاعاهـــ 999 ام مؤسسة الرسالة - بيروت. (「q)

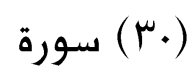

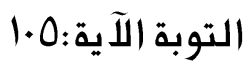
(اس ) سورة الذاريات ، الأية 07.

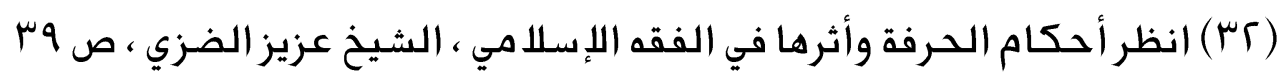
مرجع سابق.

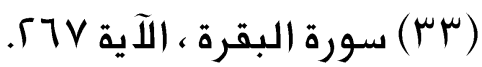

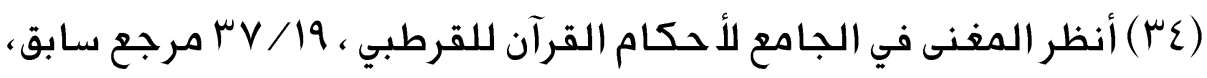
وكذلك أنظر كتاب أحكام الحرفة وآثارها للشيخ عزيز بن فرحان ، ص اه مرجع 


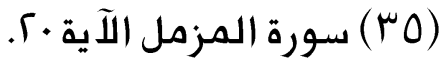

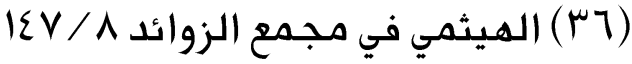

$$
\begin{aligned}
& \text { سورة المائدة ، الآية (YV) }
\end{aligned}
$$

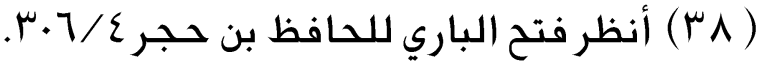

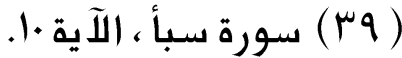

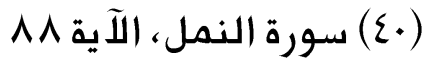

$$
\begin{aligned}
& \text { 0. } \\
& \text { ( الجامع لشعب الإيمان - البيهقي 9) }
\end{aligned}
$$

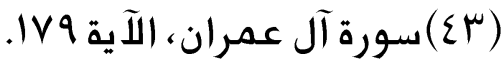

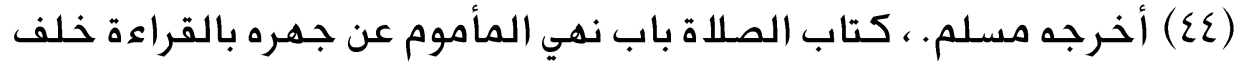

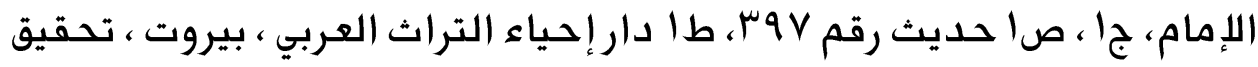

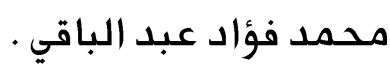

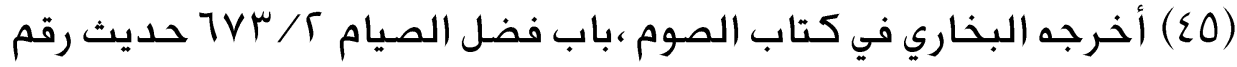

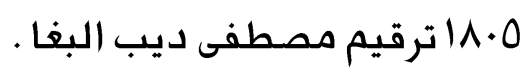

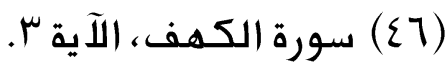
IV9 آل عمران (\&V) (乏^)

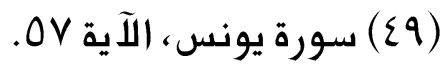

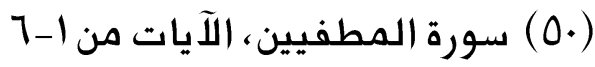

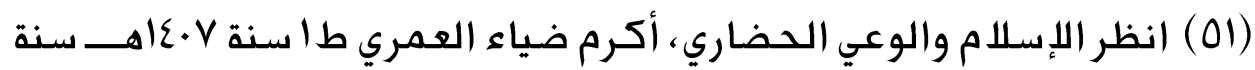

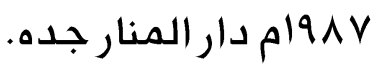

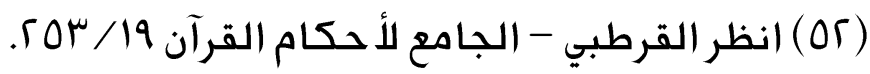

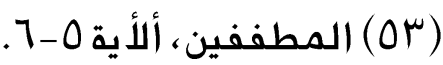

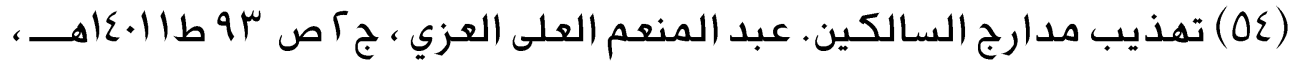

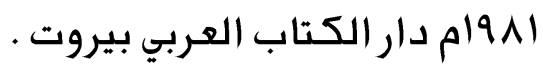

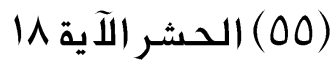




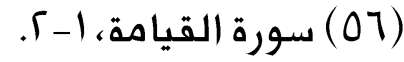

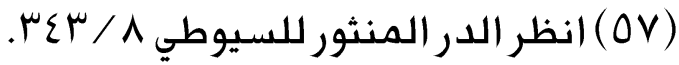

$$
\text { r. (OA) }
$$

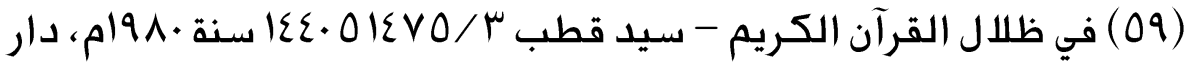

$$
\text { الشروف - بيروت ، لبنان. }
$$

(7) نقلاً من كتاب المسار لمحمد أحمد الراشد، ص كالحع لم أقف على شاعر الأبيات.

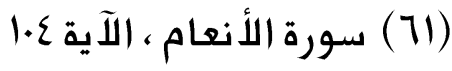

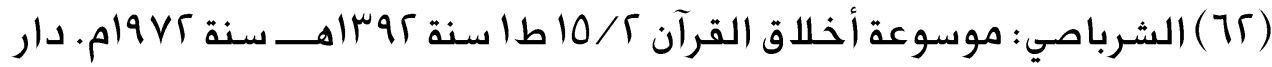
الرائد العربي - بيروت - لبنان.

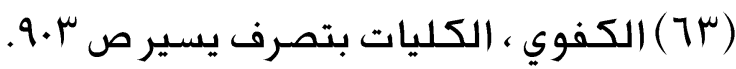

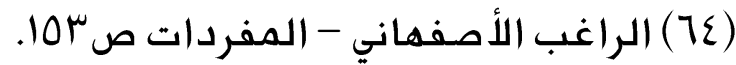

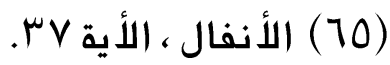

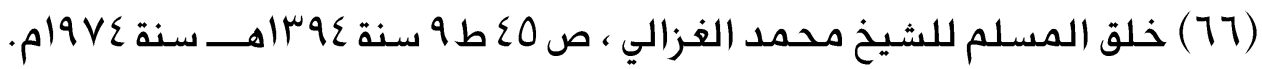
مطبعة قطرالوطنية - الدوحة - قطر

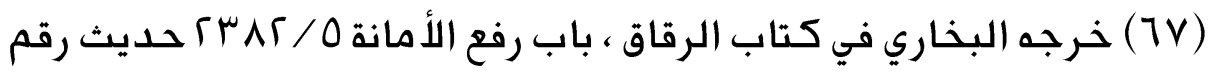

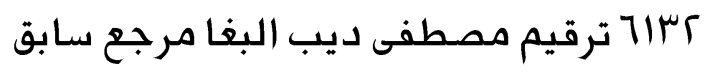

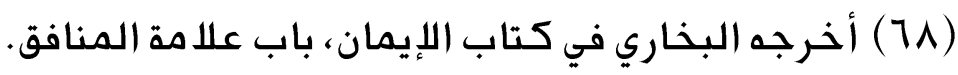

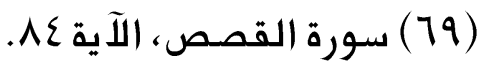

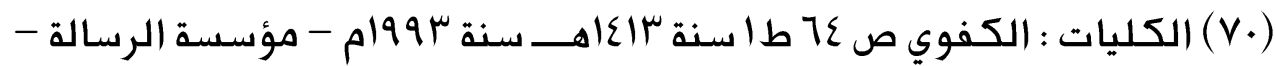
بيروت. (VI) - بيروت. سورة سبأ ، الآية VV)

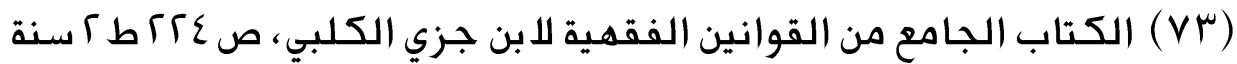

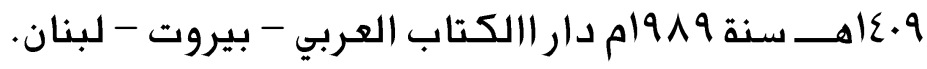




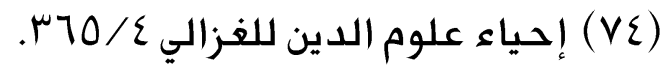

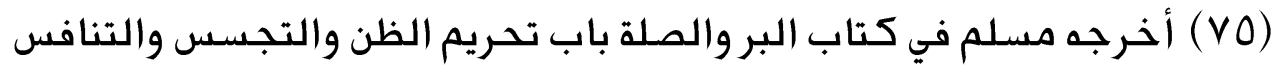

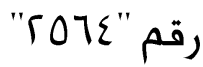
(VT) صحيح مسلم ، حديث رقم SVTO وسنن أبي داؤود ع /. إ حديث رقم (VV) (VA)

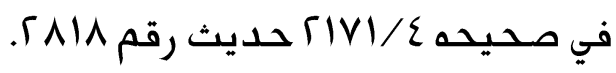

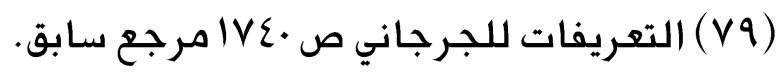

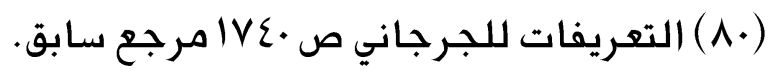

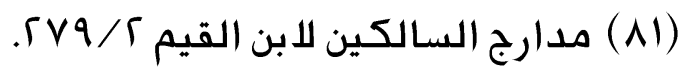
(AT) العلمية - بيروت

(Ar)

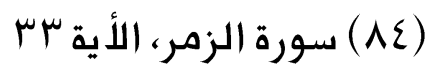
(^0) عبد الرحمن ناصر السعدي تيسير الكريم الرحمن في تفسير كلام النان سورة الزمر. سورة النمل ، الأية 1.0 أخرجه البخاري في ،كتاب الإيمان باب علامة المنافق / (AV)

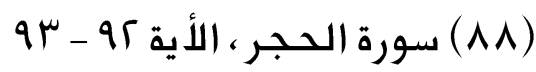

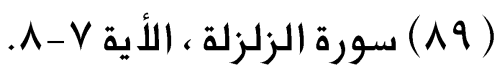

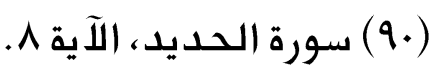

